\title{
Form of the Nitrogen Source Affects the Response of the Two Congeneric Rumex Species to Phosphorus Nutrition in The Nile Delta Coast
}

\author{
Taha M. El-Katony $^{* 1}$, A. A. Khedr ${ }^{1}$, S. S. Abo-Shosha ${ }^{1}$, A. F. El-Biany ${ }^{1}$ and I. A. Omar ${ }^{1}$ \\ ${ }^{1}$ Department of Botany and Microbiology, Faculty of Science, Damietta University, New Damietta 34517, Egypt
}

Received: 3 January 2021 /Accepted: 18 January 2021

* Corresponding author's E-mail: tmsoliman@du.edu.eg

\begin{abstract}
Phosphorus and nitrogen are limiting plant nutrients in young and old weathered soils, respectively. We investigated the $\mathrm{N} \times \mathrm{P}$ interaction on performance of Rumex dentatus and $R$. pictus. Plants were grown on washed sand and supplied with $11 \mathrm{mM} \mathrm{N}$ either as nitrate or ammonium and 0.01, 0.15, $0.40,1.0$ and $1.5 \mathrm{mM}$ P. Rumex, particularly $R$. dentatus, preferred nitrate over ammonium as $\mathrm{N}$ source. Nitrate nutrition favored succulence of $R$. dentatus but the reverse was true in $R$. pictus. The optimum P supply of Rumex spp. under nitrate $(0.4 \mathrm{mM})$ was lower than that under ammonium nutrition (1.5 mM P). R. dentatus exhibited less number of leaves but longer and wider blades compared with $R$. pictus. Allocation of plant biomass to root was favored under ammonium nutrition and $\mathrm{P}$ deficiency, particularly in $R$. pictus. Increasing $\mathrm{P}$ supply increased $\mathrm{Chl}$ a and carotenoid concentrations but reduced $\mathrm{Chl} b$ concentration. Soluble sugars were higher under nitrate nutrition compared with ammonium only in $R$. pictus, with limited effect of $\mathrm{P}$ supply. The higher proline concentration under ammonium compared with nitrate nutrition and under $\mathrm{P}$ deficiency is not a consequence of impaired protein synthesis and suggests that ammonium might be stressful, particularly to $R$. dentatus. Only in $R$. dentatus, nitrate nutrition led to higher phenolic concentration and DPPH scavenging activity but to lower malondialdehyde content relative to ammonium. Increasing P supply increased phenolic concentration and DPPH scavenging activity but reduced malondialdehyde content. The concentrations of $\mathrm{K}+$ and $\mathrm{Na}+$ in the shoot were non-significantly affected by the form of $\mathrm{N}$ but exhibited marked genotypic variability in favor of $R$. dentatus. Increasing $\mathrm{P}$ supply non-significantly affected shoot $\mathrm{K}+$ concentration but reduced $\mathrm{Na}+$ concentration. Shoot nitrogen concentration was higher in $R$. dentatus than $R$. pictus and under nitrate over ammonium nutrition only in $R$. pictus. The increase in $\mathrm{P}$ supply increased $\mathrm{P}$ concentration particularly in the ammonium-fed plants. Phosphorus concentration of the shoot was significantly higher in $R$. pictus than $R$. dentatus under ammonium nutrition but the reverse was true under nitrate nutrition.
\end{abstract}

Keywords: Rumex dentatus, Rumex pictus, nitrogen, phosphorus, minerals.

\section{Introduction}

Phosphorus is required for a wide variety of functions in the plant, e.g. as a structural component in nucleic acids, phospholipids and phytin of seeds, in the phosphorylated 
intermediates of plant metabolism and in activation of enzymes (Hawkesford et al., 2012). Along with $N$ and $K$, adequate $P$ supply is necessary for optimum plant growth and performance and must be added periodically to the cultivated lands for sustained productivity. However, similar to K and unlike N, P is a nonrenewable resource. While $\mathrm{N}$ reservoirs occur in the atmosphere, as the inert dinitrogen gas $\left(\mathrm{N}_{2}\right)$, which can be fixed either symbiotically or by free living prokaryotes, $\mathrm{P}$ is derived mainly from rock phosphate. Globally $\mathrm{P}$ reserves are subjected to severe depletion. Whereas $\mathrm{P}$ deprivation is common in old severely weathered soils that have high concentrations of the P-sorbant oxides and hydroxides of aluminium and iron, $\mathrm{N}$ is limiting to plant productivity in young soils of low content of organic matter (Lambers et al., 2015).

Based on the current rates of consumption, the global $\mathrm{P}$ reserves are estimated to be halved (relative to their levels at the onset of the 20th century) very soon in 2040 or if we are fortune in 2060 (Lambers et al., 2006). Surprisingly, while the global P reserves are being depleted, $\mathrm{P}$ levels in many agricultural soils are building up, because $80-90 \%$ of the $\mathrm{P}$ applied as fertilizer is sorbed by soil particles, and thus is rendered unavailable for most crop plants. There is an urgent need to manipulate crops that are more efficient at acquiring inorganic $\mathrm{P}(\mathrm{Pi})$ from impoverished soil and/or with high internal $P$ use efficiency. Equally, it is increasingly important to cultivate crops that reduce the off-site effects of $P$ fertilization, thus reducing the risks of polluting streams and rivers (Simpson et al., 2011).

Meanwhile, agricultural soils that have been fertilized or over-fertilized for decades, contain substantial amounts of $\mathrm{P}$ not readily accessible by crop plants since these domesticated plant species mostly lack the necessary specific root adaptation mechanisms to acquire $\mathrm{P}$ from the otherwise recalcitrant resources (Lambers et al, 2006). By comparison, the efficient Pacquisition traits are rather well-expressed in the wild relatives. To acquire soil orthophosphate (Pi) more efficiently, crop plants must develop some traits primarily concerning the root. These qualifying traits include increasing investment of the plant biomass in the production of root, production of roots with special architecture and performance and production of cluster or proteoid roots. Alteration of root architecture involves inhibition of primary root growth in favor of promotion of lateral root growth and enhancement of root hair development. Proteoid roots represent a combination of both morphological and functional adaptations (McKay Fletcher et al., 2020). These morphological adaptations are triggered by changes in $\mathrm{P}$ partitioning within the plant which is mediated by growth regulators such as auxins, ethylene, cytokinins, nitric oxide (NO), reactive oxygen species (ROS) and abscisic acid (ABA) (Niu et al., 2013). The functional adaptation traits include release of acid phosphatases, protons and/or carboxylates into the rhizosphere which increases the concentration of soluble $\mathrm{Pi}$ in the soil and hastens $\mathrm{P}$ availability to the efficient species as well as to their neighbors (He et al., 2020). Nevertheless, there is a trade-off in which the species most proficient at acquiring $\mathrm{P}$ have ephemeral roots with high susceptibility to soilborne pathogens (Laliberté et al., 2015).

Unlike nitrate, which is readily mobile in the soil, $\mathrm{Pi}$ is highly soil-immobile in contrast to its high mobility in the plant. Diffusion of mineral nutrients, particularly $\mathrm{Pi}$, is further slowed down in dry soil (Lambers and Plaxton, 2018), which aggravates the $\mathrm{P}$ problem in arid lands. Increasing Pi delivery to roots via mass flow can be achieved by enhanced transpiration rates; but this would be at the expense of a plant's water-use efficiency. Diffusion of Pi toward the root can be increased by increasing the moisture content of dry soil, or by increasing the Pi concentration in soil solution through release of Pi from complexed, sorbed or organic forms of $\mathrm{P}$.

Rumex is one of the most important genera of Polygonaceae, with cosmopolitan distribution in temperate regions. Rumex species have a long history of domestic herbal use because of their high content of vitamins, particularly vitamins $\mathrm{A}$ and $\mathrm{C}$ as well as minerals, especially iron (Vasas et al., 2015). It is a gentle laxative, compared with rhubarb, with valuable cleansing properties and is useful for treating a wide range of skin problems. Rumex dentatus L. (dentate dock) is an annual glabrous herb with slender, erect stems of $70-80 \mathrm{~cm}$ in height. In grows wildly in abandoned lands, canal banks and cultivated fields. It has been used as a leafy vegetable in the Mediterranean diet (Mashaly et al., 2015). A related species, Rumex pictus Forssk., is annual glabrous herb, with $10-30 \mathrm{~cm}$ high stems, decumbent and highly branched at 
the base. It dominates the sand formations (dunes and flats) in the Nile Delta coast (Mashaly et al., 2008). This study investigates the effect of form of nitrogen on phosphorus nutrition of two congeneric species of Rumex, R. dentatus and R. pictus which exhibit different ecological niches and growth habits.

Materials and Methods

The study area

The study area is located within the northern part of the Nile Delta, and involved the cultivated lands about $10 \mathrm{~km}$ south of the sea coast (for Rumex dentatus L.) and the sand plains and sand dunes immediately at the sea shore (for R. pictus Forssk.) (Figure 2.1). The soil characteristics of the two sites are presented in Table 2.1.

Soil analysis

Three soil samples $(0-10 \mathrm{~cm}$ in depth) were collected from each site. The three samples were air-dried, mixed into a homogenous sample, passed through a $2 \mathrm{~mm}$ sieve, and packed in paper bags for analysis. Soil texture was determined according the procedures of (Jackson, 1962). The $\mathrm{pH}$, electrical conductivity (EC), carbonate, bicarbonate, and minerals were determined in the soil extract (1:5). The $\mathrm{pH}$ and $\mathrm{EC}$ were measured using a $\mathrm{pH}$ meter (Hanna HI 2210) and conductivity meter (HI 9835), respectively. Potassium, sodium and calcium of the soil extract were measured by using a PFP7 Flame Photometer. Chloride content of the soil extract was determined by titration against standard $\mathrm{AgNO} 3$ using 5\% potassium chromate as an Indicator (Jackson, 1962). The organic carbon content of the soil was determined by titration against $\mathrm{FeSO} 4$ as described of Piper (1947). Determination of carbonates and bicarbonates in the soil extract were according to the method described by Jackson (1962). This method is volumetric, using $0.1 \mathrm{~N} \mathrm{HCl}$ and phenolphthalein and methyl orange as indicators. The concentrations of $\mathrm{N}$ and $\mathrm{P}$ were determined using an autoanalyzer (QuikChem, Series 8000, Lachat Instruments Inc., USA).

Plant material

Seeds of Rumex dentatus L. were collected from the cultivated lands $50 \mathrm{~km}$ south of the New Damietta city and seeds of Rumex pictus Forssk. from the coastal sand plains at Gamasa city, north of Egypt. Soil analysis of the natural habitats of the two Rumex species is presented in Table 1. Fruits were collected from mature plants during the period May-June, 2017 and left to dry in the sun until constant weight. Dry fruits were hand-rubbed to extract seeds, and the seeds were screened for homogeneity in shape and color and stored in paper bags before cultivation.

Interaction of $\mathrm{N}$ form and phosphorus on growth and physiology of Rumex spp.

Uniform seeds of R. dentatus L. and R. pictus Forssk. were washed thoroughly with tap water and planted in plastic pots of $30 \mathrm{~cm}$ diameter, full of $5 \mathrm{~kg}$ of water-washed sand, three seeds per pot. Seeds were watered with $0.2 \mathrm{mM}$ $\mathrm{CaSO} 4$, and the emerging seedlings, while at the rosette stage, were successively thinned to one per pot. After 30 days from sowing, seedlings received a full nutrient solution containing $11 \mathrm{mM} \mathrm{N}$ supplied either as NO3- or $\mathrm{NH} 4+$. The macronutrient composition of nutrient solutions is presented in Table 2.

In addition to macronutrients, nutrient solutions contained the following micronutrients $(\mu \mathrm{M})$ : $\mathrm{Mn}$ (as MnSO4.4 H2O) 5, Cu (as CuSO4.5 $\mathrm{H} 2 \mathrm{O}$ ) 0.5, $\mathrm{Zn}$ (as $\mathrm{ZnSO} 4.7 \mathrm{H} 2 \mathrm{O}$ ) 0.5, B (as boric acid) 25, Mo (as Na2MoO4.2 H2O) 0.25 and $\mathrm{Co}$ (as $\mathrm{CoSO} 4$ ) 0.1. Phosphorus was added to the nitrate and ammonium solutions as $\mathrm{NaH} 2 \mathrm{PO} 4$ at levels of $0.01,0.15,0.40,1.0$ and $1.5 \mathrm{mM}$. The $\mathrm{pH}$ was adjusted to $6-6.5$ by using drops of $1 \mathrm{~N} \mathrm{HCl}$ and $1 \mathrm{~N} \mathrm{NaOH}$, if required.

Plants were grown in a greenhouse at the Faculty of Agriculture, Alexandria University during the period from November 2017 to May 2018. Irradiance ranged from 1500 to 2000 $\mu \mathrm{mol} \mathrm{m}-2 \mathrm{~s}-1$ from natural sunlight, with a temperature of $27 / 20^{\circ} \mathrm{C}$ in a $14 / 10 \mathrm{~h}$ light/dark period and relative humidity of about $70 \%$ in average.

Table 1 Analysis of the soil from the natural habitats of $R$. dentatus and $R$. pictus.

\begin{tabular}{|c|c|c|}
\hline Characteristic & R. dentatus & R.pictus \\
\hline Texture & Sandy clay loam & Sandy \\
\hline $\mathrm{EC}(\mathrm{dS} / \mathrm{m})$ & 1.18 & 1.14 \\
\hline $\mathrm{pH}$ & 7.25 & 7.18 \\
\hline Organic carbon (\% DW) & 1.77 & 0.8 \\
\hline $\mathrm{CO}_{3}{ }^{2-}(\mathrm{mg} / \mathrm{g} \mathrm{DW})$ & 0 & 0 \\
\hline $\mathrm{HCO}_{3}^{-}(\mathrm{mg} / \mathrm{g} \mathrm{DW})$ & 204 & 183 \\
\hline N (mg/g DW) & 168.8 & 122 \\
\hline $\mathrm{P}(\mathrm{mg} / \mathrm{g} \mathrm{DW})$ & 11 & 4.1 \\
\hline $\mathrm{K}(\mathrm{mg} / \mathrm{g} \mathrm{DW})$ & 28 & 24.1 \\
\hline $\mathrm{Ca}(\mathrm{mg} / \mathrm{g} \mathrm{DW})$ & 54.1 & 46.8 \\
\hline $\mathrm{Mg}(\mathrm{mg} / \mathrm{g} \mathrm{DW})$ & 24 & 16.8 \\
\hline $\mathrm{Na}(\mathrm{mg} / \mathrm{g} \mathrm{DW})$ & 130.1 & 126.2 \\
\hline $\mathrm{Cl}$ (mg/g DW) & 101 & 133.6 \\
\hline $\mathrm{Fe}(\mu \mathrm{g} / \mathrm{g} \mathrm{DW})$ & 9.0 & 11 \\
\hline $\mathrm{Zn}(\mu \mathrm{g} / \mathrm{g} D W)$ & 11 & 2 \\
\hline $\operatorname{Mn}(\mu \mathrm{g} / \mathrm{g} D W)$ & 11 & 2 \\
\hline $\mathrm{Cu}(\mu \mathrm{g} / \mathrm{g} \mathrm{DW})$ & 116 & 61 \\
\hline
\end{tabular}


Table 2 The composition of macronutrients in the ammonium and nitrate solutions

\begin{tabular}{lcr}
\multicolumn{1}{c}{ Nitrate solution } & & \\
\cline { 1 - 2 } \multicolumn{1}{c}{ Chemical } & mM $=11$ \\
$\mathrm{KNO}_{3}$ & 5 & $\mathrm{~K}=5$ \\
$\mathrm{Ca}\left(\mathrm{NO}_{3}\right)_{2} .4 \mathrm{H}_{2} \mathrm{O}$ & 3 & $\mathrm{Ca}=3$ \\
$\mathrm{MgCl}_{2}$ & 1 & $\mathrm{Mg}=1$ \\
$\mathrm{Na}_{2} \mathrm{SO}_{4}$ & 8 & $\mathrm{~S}=8$ \\
FeEDTA & 0.1 & $\mathrm{Cl}=2$ \\
\cline { 1 - 1 } & &
\end{tabular}

\begin{tabular}{lll}
\multicolumn{1}{c}{ Ammonium solution } & \\
\cline { 1 - 2 } Chemical & $\mathrm{mM}$ & $\mathrm{N}=11$ \\
\cline { 1 - 2 }$\left(\mathrm{NH}_{4}\right)_{2} \mathrm{SO}_{4}$ & 5.5 & $=5 \mathrm{Ca}$ \\
$\mathrm{CaCl}_{2}$ & 3 & 1 \\
$\mathrm{MgSO}_{4} .7 \mathrm{H}_{2} \mathrm{O}$ & 1 & $\mathrm{~S}=9$ \\
$\mathrm{~K}_{2} \mathrm{SO}_{4}$ & 2.5 & $\mathrm{Cl}=6 \mathrm{Na}$ \\
FeEDTA & 0.1 & $=0$ \\
\cline { 1 - 1 } & &
\end{tabular}

Plants were harvested 170 days from the application of nutrient solutions. At harvest, plants were thoroughly washed from sand, separated into shoot and root, blotted gently and fresh weights, plant height and leaf dimensions were recorded. An aliquot of fresh leaves was kept frozen at $-10{ }^{\circ} \mathrm{C}$ for estimation of photosynthetic pigments and metabolites. Dry weights were recorded after drying of the fresh plant material at $80{ }^{\circ} \mathrm{C}$ for $48 \mathrm{~h}$ and were corrected for the leaf portion kept frozen.

\section{Plant analysis}

\section{Estimation of photosynthetic pigments}

Photosynthetic pigments were determined according to the method described of Wellburn and Lichtenthaler (1984). Frozen leaf discs were macerated in $80 \%$ acetone using a cold mortar and pestle in dim light with a pinch of magnesium carbonate to neutralize the plant acids. The slurry was centrifuged at $18000 \times g$ for $5 \mathrm{~min}$ and the clear extract was brought up to volume with $80 \%$ acetone and the absorbance was read at 470, 646 and $663 \mathrm{~nm}$ using a UNICO 7200 series spectrophotometer. The concentrations of chlorophyll a, chlorophyll b and carotenoids were calculated $\left(\mu \mathrm{g} \mathrm{ml}^{-1}\right)$ using the following equations:

Chlorophyll $\mathrm{a}=12.21$ E663 -2.81 E646

Chlorophyll $b=20.13$ E646 - 5.03 E663

Carotenoids $=\frac{\left(1000 \mathrm{E}_{470}-3.27 \mathrm{Chla}-104 \mathrm{Chl} \mathrm{b}\right)}{229}$

\section{Estimation of proline content}

According to Bates et al. (1973), a known weight of frozen leaves was homogenized in 4 $\mathrm{ml}$ of $3 \%$ sulfosalicylic acid and the slurry was centrifuged at $18000 \times g$ for $10 \mathrm{~min}$. To $1 \mathrm{ml}$ of the clear extract, $1 \mathrm{ml}$ glacial acetic acid and 1 $\mathrm{ml}$ of the acid ninhydrin reagent were added. The reaction mixture was boiled in a water bath for $60 \mathrm{~min}$. After cooling in an ice bath, $4 \mathrm{ml}$

toluene were added and the contents were mixed thoroughly. The upper toluene phase was separated into a glass cuvette and absorbance was read at $520 \mathrm{~nm}$. Proline concentration was calculated from a standard curve in the range of $0-100 \mu \mathrm{g}$ proline. Acid-ninhydrin reagent was freshly prepared by warming $1.25 \mathrm{~g}$ ninhydrin in $30 \mathrm{ml}$ glacial acetic acid and $20 \mathrm{ml}$ of $6 \mathrm{M}$ phosphoric acid, with agitation, until dissolved.

\section{Determination of soluble sugars}

A known weight of the frozen leaf material was extracted in $1 \mathrm{ml}$ of boiling $80 \%$ ethanol for 30 minutes and the mixture was centrifuged at $8000 \times g$ for $10 \mathrm{~min}$. Extraction was repeated with fresh $80 \%$ ethanol, followed by centrifugation and extracts were bulked. The supernatant was evaporated to dryness at $70{ }^{\circ} \mathrm{C}$, re-dissolved in distilled water and an aliquot was completed to $1 \mathrm{ml}$ by distilled water, mixed carefully with $3 \mathrm{ml}$ of the anthrone reagent (8.6 $\mathrm{mM}$ anthrone in $80 \% \mathrm{v} / \mathrm{v} \mathrm{H}_{2} \mathrm{SO}_{4}$ ) and heated in a water bath at $80{ }^{\circ} \mathrm{C}$ for $10 \mathrm{~min}$. After cooling in an ice bath, absorbance was read at $623 \mathrm{~nm}$ against the reagent blank. Total soluble sugars were estimated from a glucose calibration curve in the range of 0 to $100 \mu \mathrm{g}$ glucose (Schlüter and Crawford, 2003).

\section{Assay of protein}

A known weight of the frozen leaf material was grinded in liquid nitrogen using a pestle and mortar, and the slurry was extracted in $600 \mu \mathrm{l}$ of $50 \quad \mathrm{mM}$ 4-(2-hydroxyethyl)-1piperazineethanesulfonic acid (HEPES, $\mathrm{pH}$ 7.4) containing $1 \mathrm{mM}$ EDTA and $6 \mu \mathrm{l}$ of $500 \mathrm{mM}$ of phenylmethane sulfonyl fluoride (PMSF) prepared in methanol. The debris was removed by centrifugation at $6000 \times g$ for $10 \min$ at $4{ }^{\circ} \mathrm{C}$. Protein content of leaves was assayed according to the method of Bradford (1976). An aliquot of the supernatant was raised to $1 \mathrm{ml}$ with 
distilled water and mixed with $5 \mathrm{ml}$ Coomassie brilliant blue reagent. After standing for $5 \mathrm{~min}$ at room temperature, absorbance was read at $595 \mathrm{~nm}$ using a Spectronic $20 \mathrm{D}$ spectrophotometer. Protein concentration was calculated using a standard curve of bovine serum albumin (BSA) in the range $0-100 \mu \mathrm{g}$. Coomassie brilliant blue reagent was prepared by dissolving $100 \mathrm{mg}$ of Coomassie brilliant blue G- ${ }^{\circ} 00$ in $50 \mathrm{ml}$ of $95 \%$ ethanol mixed with $100 \mathrm{ml}$ of $85 \%$ phosphoric acid. The stock dye reagent was kept at $4{ }^{\circ} \mathrm{C}$ and diluted immediately before use; where $15 \mathrm{ml}$ of the stock reagent was raised to $100 \mathrm{ml}$ with distilled water and filtered whenever necessary.

\section{Digestion of plant material and determination of mineral content}

Dried plant material was ground into a fine powder and digested in the sulfuric acid/hydrogen peroxide mixture as described by Allen et al. (1986). Temperature was increased gradually until complete digestion of plant material. After cooling, the extract was made up to volume with distilled water. A blank test was prepared by heating the digestion mixture without plant material. Digestion mixture was prepared by mixing $0.42 \mathrm{~g}$ selenium and $14 \mathrm{~g}$ lithium sulfate hydrated in a one-liter flask. To the mixture $350 \mathrm{ml} \mathrm{H}_{2} \mathrm{O}_{2}$ (100 volume) and 420 $\mathrm{ml}$ conc. $\mathrm{H}_{2} \mathrm{SO}_{4}$ were added slowly in order with cooling. Potassium and sodium were determined in the clear extract by using a Jenway PFP7 flame photometer. The concentrations of $\mathrm{N}$ and $\mathrm{P}$ were determined using an auto-analyzer (QuikChem, Series 8000, Lachat Instruments Inc., USA).

\section{Assay of free phenolics}

Free phenolics were extracted by incubating a known weight of the frozen leaves in $95 \%$ ethanol for 2 hours at room temperature in a rotary shaker at $250 \mathrm{rpm}$. The mixture was centrifuged at $8000 \times g$ for 10 minutes at room temperature. Free phenolic acids were estimated according to the method of Ainsworth and Gillespie (2007). An aliquot of the ethanolic extract was raised to $1 \mathrm{ml}$ with distilled water and $3.5 \mathrm{ml}$ of $0.2 \mathrm{~N}$ FolinCiocalteu reagent were added. After 3-5 min., $2.5 \mathrm{ml}$ of $7.5 \% \quad \mathrm{Na}_{2} \mathrm{CO}_{3}$ were added and the mixture was incubated at $45^{\circ} \mathrm{C}$ for $15 \mathrm{~min}$., then cooled to room temperature and absorbance of the resulting blue color was measured at 765 $\mathrm{nm}$. Phenolics were estimated with reference to a standard curve using gallic acid in the range of $0-100 \mu \mathrm{g}$; and the concentration was expressed as $\mu \mathrm{g}$ gallic acid equivalent $(\mu \mathrm{g}$ GAE) $\mathrm{g}^{-1} \mathrm{FW}$.

\section{DPPH scavenging activity}

The capacity of the leaf extract to scavenge the stable free radical 2,2-diphenyl-1picrylhydrazyl (DPPH) was monitored according to the method of Hatano et al. (1988). An aliquot of $0.3 \mathrm{ml}$ of the ethanolic extract was mixed with $2.7 \mathrm{ml}$ of DPPH solution $\left(6 \times 10^{-5} \mathrm{~mol} \mathrm{l}^{-1}\right)$. The mixture was shaken vigorously and left to stand for $60 \mathrm{~min}$ in the dark to attain stable absorbance. The reduction of the DPPH radical was measured by monitoring continuously the decrease in absorbance at $517 \mathrm{~nm}$. The DPPH scavenging activity was calculated as a percentage of DPPH discoloration using the equation:

DPPH scavenging activity $=\frac{\left(A_{d}-A_{c}\right)}{A_{d}} \times 100$ where $A_{c}$ is absorbance of the sample and $A_{d}$ absorbance of the DPPH solution.

\section{Assay of lipid peroxidation}

Lipid peroxidation of the leaf tissue was assayed by measuring the malondialdehyde (MDA) content following the method of Heath and Paker (1968). An aliquot of the frozen leaf material was grinded in liquid nitrogen using pestle and mortar and extracted in $1.3 \mathrm{ml}$ of $0.1 \%$ (w/v) trichloroacetic acid. The homogenate was centrifuged $8000 \times g$ and the supernatant was used for the assay of MDA. The reaction mixture - containing $0.5 \mathrm{ml}$ of the supernatant and $2 \mathrm{ml}$ of $0.5 \%$ thiobarbituric acid prepared in $20 \%$ (w/v) trichloroacetic acid - was incubated in a water bath at $95{ }^{\circ} \mathrm{C}$ for $30 \mathrm{~min}$. After cooling in an ice bath, the reaction mixture was centrifuged at $12000 \times g$ for 10 $\min$. The absorbance was read at $532 \mathrm{~nm}$ against the reagent blank. Correction for unspecific absorbance was performed by subtracting the absorbance at $600 \mathrm{~nm}$. MDA concentration was calculated using an extinction coefficient of 155 $\mathrm{mM}^{-1} \mathrm{~cm}^{-1}$.

\section{Experimental design and statistical analysis}


The experiment was factorial with three factors and 4 replications in a completely randomized design. The main factors were 1) plant species with two levels: $R$. dentatus and $R$. pictus, 2) nitrogen form with two levels: nitrate and ammonium both at $11 \mathrm{mM} \mathrm{N}$ and 3) P nutrition with five levels: $0.01,0.15,0.40,1.0$ and 1.5 $\mathrm{mM}$. Data were subjected to three-way ANOVA using SPSS version 22, followed by mean separation according to the Duncan's multiple range test at $\mathrm{p}<0.05$.

\section{Results}

Plant growth was highly significantly $(\mathrm{P}<0.01)$ affected by the main factors: plant species, nitrogen source and level of phosphorus, except for the non-significant effect of species and nitrogen form on shoot water and plant height and of phosphorus level on the root weight ratio (RWR) and the width/ length ratio of blade. The effect of the factor interactions was less evident than the effect of the main factors, ranging from just significant $(\mathrm{P}<0.05)$ to mostly nonsignificant (Table 3).

The effect of genotype on shoot dry weight was very weak under ammonium nutrition with comparable values in the two Rumex species. But, the genotypic variability emerged convincingly under nitrate nutrition with superiority of $R$. dentatus above $R$. pictus. In turn, the differential effect of nitrogen form was evident only in $R$. dentatus, in which shoot dry weight was higher in nitrate-fed than ammonium-fed plants versus a mild preference of nitrate by $R$. pictus. Increasing $\mathrm{P}$ level of the medium increased shoot dry weight with a tendency towards saturation beyond $0.4 \mathrm{mM} \mathrm{P}$. The magnitude of increase was generally higher under ammonium than under nitrate nutrition and in $R$. dentatus than $R$. pictus. The overall increase in shoot dry weight across the whole range of $\mathrm{P}$ amounted to $38 \%$ and $115 \%$ for nitrate- and ammonium-fed $R$. dentatus, respectively and $29 \%$ and $44 \%$ for nitrate- and ammonium-fed $R$. pictus, respectively (Fig. 1A).

Root dry weight was significantly higher in $R$. dentatus above $R$. pictus. However, the differential effect of $\mathrm{N}$ from was evident only in $R$. dentatus, with preference of nitrate over ammonium versus a comparable root dry weight in the two nitrogen forms of $R$. pictus. Increasing $\mathrm{P}$ level of the medium led to progressive increase in root dry, with the effect being most pronounced in nitrate-fed $R$. dentatus. The overall increase in root dry weight across the whole range of $\mathrm{P}$ amounted to $64 \%$ and $112 \%$ for nitrate- and ammonium-fed $R$. dentatus, respectively versus non-significant increases of $23 \%$ in the average for nitrate- and ammonium-fed $R$. pictus (Fig. 1B).

The RWR was significantly higher in $R$. dentatus above $R$. pictus. However, the differential effect of $\mathrm{N}$ from was evident only in $R$. pictus, with higher RWR under ammonium compared to nitrate nutrition, particularly under low $\mathrm{P}$ levels versus comparable values in the two nitrogen forms of $R$. dentatus. The effect of $\mathrm{P}$ level on the RWR varied according to plant species and from of $\mathrm{N}$. In ammonium-fed plants, increasing $\mathrm{P}$ supply from 0.01 to 0.4 $\mathrm{mM}$ reduced RWR of $R$. dentatus by $21 \%$, followed by $20 \%$ increase as $\mathrm{P}$ level further increased up to $1.5 \mathrm{mM}$, versus a $34 \%$ decrease across the whole $\mathrm{P}$ range in $R$. pictus. In nitratefed plants, RWR of the two species was nonsignificantly affected by $\mathrm{P}$ level of the medium (Fig. 1C).

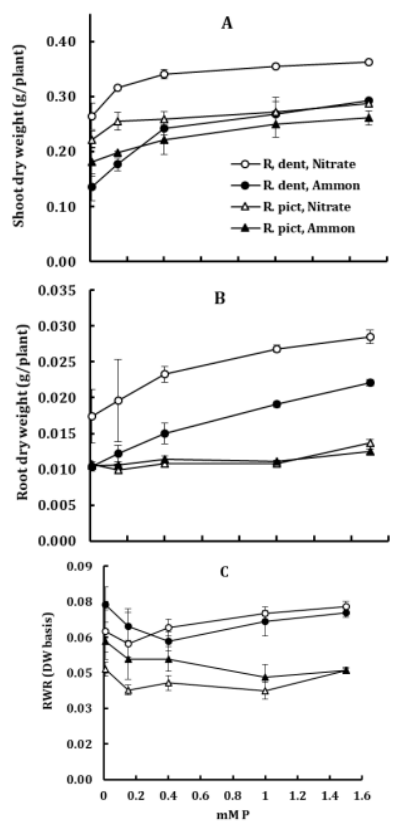

Figure 1 Shoot dry weight (A), root dry weight (B) and the root weight ratio (RWR, C) of $R$. dentatus and $R$. pictus in response to increasing level of $\mathrm{P}$ in a hydroponic culture with $11 \mathrm{mM} \mathrm{N}$ supplied either as $\mathrm{NO}_{3}{ }^{-}$or $\mathrm{NH}_{4}{ }^{+}$. Each value is the mean of 4 replicates $\pm \mathrm{SE}$. 
Table 3 Three-way ANOVA showing the effect of the main factors (Rumex species, $\mathrm{N}$ form and level of $\mathrm{P}$ ) and their interaction on plant growth.

\begin{tabular}{|c|c|c|c|c|c|c|c|}
\hline $\begin{array}{c}\text { Variable and } \\
\text { source of variation }\end{array}$ & df & $\mathbf{F}$ & $\mathbf{P}$ & $\begin{array}{c}\text { Variable and } \\
\text { source of variation }\end{array}$ & df & $\mathbf{F}$ & $\mathbf{P}$ \\
\hline Shoot dry weight & & & & Leaf width & & & \\
\hline Species (Sp.) & 1 & 9.029 & 0.004 & Species (Sp.) & 1 & 357.3 & 0.000 \\
\hline $\mathrm{N}$ form $(\mathrm{N})$ & 1 & 96.39 & 0.000 & $\mathrm{~N}$ form $(\mathrm{N})$ & 1 & 13.53 & 0.001 \\
\hline P level (P) & 4 & 33.00 & 0.000 & P level (P) & 4 & 23.19 & 0.000 \\
\hline Sp. $\times N$ & 1 & 15.67 & 0.000 & Sp. $\times N$ & 1 & 0.265 & 0.609 \\
\hline Sp. $\times$ P & 4 & 3.109 & 0.022 & Sp. $\times \mathrm{P}$ & 4 & 1.804 & 0.140 \\
\hline $\mathrm{N} \times \mathrm{P}$ & 4 & 0.825 & 0.515 & $\mathrm{~N} \times \mathrm{P}$ & 4 & 1.052 & 0.388 \\
\hline Sp. $\times \mathrm{N} \times \mathrm{P}$ & 4 & 0.428 & 0.788 & Sp. $\times N \times P$ & 4 & 1.614 & 0.182 \\
\hline Root dry weight & & & & Leaf width/length ratio & & & \\
\hline Species (Sp.) & 1 & 134.4 & 0.000 & Species (Sp.) & 1 & 51.87 & 0.000 \\
\hline $\mathrm{N}$ form $(\mathrm{N})$ & 1 & 29.87 & 0.000 & $\mathrm{~N}$ form $(\mathrm{N})$ & 1 & 18.26 & 0.000 \\
\hline $\mathrm{P}$ level (P) & 4 & 9.541 & 0.000 & P level (P) & 4 & 2.182 & 0.082 \\
\hline Sp. $\times N$ & 1 & 29.06 & 0.000 & Sp. $\times N$ & 1 & 0.219 & 0.641 \\
\hline Sp. $\times$ P & 4 & 4.076 & 0.005 & Sp. $\times$ P & 4 & 3.167 & 0.020 \\
\hline $\mathrm{N} \times \mathrm{P}$ & 4 & 0.401 & 0.808 & $\mathrm{~N} \times \mathrm{P}$ & 4 & 4.838 & 0.002 \\
\hline Sp. $\times \mathrm{N} \times \mathrm{P}$ & 4 & 0.408 & 0.802 & Sp. $\times \mathrm{N} \times \mathrm{P}$ & 4 & 2.699 & 0.039 \\
\hline RWR & & & & Shoot water & & & \\
\hline Species (Sp.) & 1 & 80.07 & 0.000 & Species (Sp.) & 1 & 2.228 & 0.141 \\
\hline $\mathrm{N}$ form $(\mathrm{N})$ & 1 & 2.716 & 0.105 & $\mathrm{~N}$ form $(\mathrm{N})$ & 1 & 0.277 & 0.601 \\
\hline $\mathrm{P}$ level $(\mathrm{P})$ & 4 & 1.219 & 0.312 & P level (P) & 4 & 4.728 & 0.002 \\
\hline $\mathrm{Sp} . \times \mathrm{N}$ & 1 & 3.226 & 0.078 & Sp. $\times N$ & 1 & 156.0 & 0.000 \\
\hline Sp. $\times$ P & 4 & 2.721 & 0.038 & Sp. $\times$ P & 4 & 3.379 & 0.015 \\
\hline $\mathrm{N} \times \mathrm{P}$ & 4 & 1.366 & 0.257 & $\mathrm{~N} \times \mathrm{P}$ & 4 & 5.710 & 0.001 \\
\hline Sp. $\times \mathrm{N} \times \mathrm{P}$ & 4 & 0.801 & 0.529 & Sp. $\times \mathrm{N} \times \mathrm{P}$ & 4 & 5.618 & 0.001 \\
\hline Number of leaves & & & & Root water & & & \\
\hline Species (Sp.) & 1 & 263.4 & 0.000 & Species (Sp.) & 1 & 297.1 & 0.000 \\
\hline $\mathrm{N}$ form $(\mathrm{N})$ & 1 & 1.182 & 0.281 & $\mathrm{~N}$ form $(\mathrm{N})$ & 1 & 9.482 & 0.003 \\
\hline P level (P) & 4 & 14.23 & 0.000 & P level (P) & 4 & 15.20 & 0.000 \\
\hline Sp. $\times N$ & 1 & 0.170 & 0.682 & Sp. $\times N$ & 1 & 40.68 & 0.000 \\
\hline Sp. $\times$ P & 4 & 11.78 & 0.000 & Sp. $\times$ P & 4 & 13.05 & 0.000 \\
\hline $\mathrm{N} \times \mathrm{P}$ & 4 & 1.993 & 0.107 & $\mathrm{~N} \times \mathrm{P}$ & 4 & 4.495 & 0.003 \\
\hline Sp. $\times \mathrm{N} \times \mathrm{P}$ & 4 & 2.007 & 0.105 & Sp. $\times \mathrm{N} \times \mathrm{P}$ & 4 & 3.749 & 0.009 \\
\hline Leaf length & & & & Plant height & & & \\
\hline Species (Sp.) & 1 & 96.61 & 0.000 & Species (Sp.) & 1 & 0.450 & 0.505 \\
\hline $\mathrm{N}$ form $(\mathrm{N})$ & 1 & 2.455 & 0.122 & $\mathrm{~N}$ form $(\mathrm{N})$ & 1 & 0.037 & 0.848 \\
\hline $\mathrm{P}$ level (P) & 4 & 9.684 & 0.000 & P level (P) & 4 & 7.273 & 0.000 \\
\hline Sp. $\times N$ & 1 & 0.090 & 0.765 & Sp. $\times N$ & 1 & 0.620 & 0.434 \\
\hline Sp. $\times$ P & 4 & 0.591 & 0.671 & Sp. $\times P$ & 4 & 0.454 & 0.769 \\
\hline $\mathrm{N} \times \mathrm{P}$ & 4 & 2.871 & 0.030 & $\mathrm{~N} \times \mathrm{P}$ & 4 & 0.425 & 0.790 \\
\hline Sp. $\times \mathrm{N} \times \mathrm{P}$ & 4 & 0.600 & 0.664 & Sp. $\times \mathrm{N} \times \mathrm{P}$ & 4 & 0.448 & 0.773 \\
\hline
\end{tabular}

Number of leaves was significantly higher in $R$. pictus than $R$. dentatus with non-significant effect of the form of $\mathrm{N}$. Irrespective of the form of $\mathrm{N}$, increasing $\mathrm{P}$ level of the medium from 0.01 to $1.5 \mathrm{mM}$ almost doubled the number of leaves in $R$. pictus with non-significant effect in $R$. dentatus (Fig. 2A). Blade length was significantly higher in $R$. dentatus than $R$. pictus with non-significant effect of the form of $\mathrm{N}$. Increasing P supply increased blade length, and the effect was more evident in $R$. dentatus than $R$. pictus and under ammonium than under nitrate nutrition. Increasing P supply from 0.01 to $1.5 \mathrm{mM}$ increased blade length by $24 \%$ and $39 \%$ in nitrate- and ammonium-fed $R$. dentatus, respectively versus respective increases of $7 \%$ and $33 \%$ (both are non-significant) for $R$. pictus (Fig. 2B).
Blade width was significantly higher in $R$. dentatus than $R$. pictus with non-significant effect of the form of N. Increasing P supply increased blade width; but the effect was more evident in $R$. pictus than $R$. dentatus and under nitrate than under ammonium nutrition. Increasing $\mathrm{P}$ level of the medium from 0.01 to $1.5 \mathrm{mM}$ increased blade width by $37 \%$ and $21 \%$ in nitrate- and ammonium-fed $R$. dentatus, respectively versus respective increases of $76 \%$ and $48 \%$ for $R$. pictus (Fig. 2C). The blade width/length ratio was significantly higher in $R$. dentatus than $R$. pictus and under ammonium than under nitrate nutrition. The differential genotypic and $\mathrm{N}$ form effects were most evident at the low P supply. Increasing P level of the medium from 0.01 to $1.5 \mathrm{mM}$ increased blade width/length ratio of nitrate-fed $R$. dentatus and 
nitrate-fed $R$. pictus by an average of $11 \%$ and that of nitrate-fed $R$. pictus by $64 \%$ but with a $15 \%$ reduction in the ammonium-fed $R$. dentatus (Fig. 2D).

Plant height was non-significantly affected by genotype and form of $\mathrm{N}$. Increasing $\mathrm{P}$ supply from 0.01 to $1.5 \mathrm{mM}$ increased plant height by an average of $23 \%$ for all genotype $\times \mathrm{N}$ from combinations (Table 4). Shoot water was subjected to significant genotype $\times \mathrm{N}$ form interaction; being higher in $R$. dentatus than $R$. pictus under nitrate nutrition while the reverse was true under ammonium nutrition. Likewise, shoot water was higher under nitrate than ammonium nutrition in $R$. dentatus but the reverse was true for $R$. pictus. Increasing $\mathrm{P}$ supply had non-significant effect on shoot water content except for the significant increase in ammonium-fed $R$. pictus across 0.01 to 0.15 $\mathrm{mM} P$ with steady values at higher $\mathrm{P}$ levels (Table 4). Root water content was significantly higher in R. dentatus than $R$. pictus and under ammonium than nitrate nutrition for $R$. pictus but with non-significant effect of $\mathrm{N}$ form in $R$. dentatus. Increasing $\mathrm{P}$ supply had nonsignificant effect on root water content of $R$. dentatus, irrespective of $\mathrm{N}$ form. By contrast, root water content of $R$. pictus was significantly increased by $11 \%$ and $6 \%$ under nitrate and ammonium nutrition, respectively across the whole range of $\mathrm{P}$ supply (Table 4).
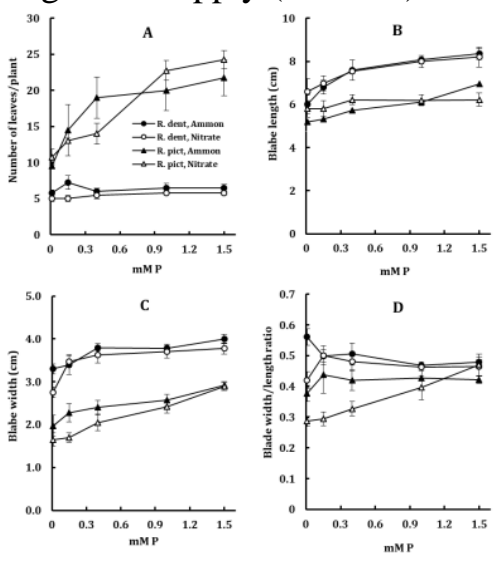

Figure 2 Number of leaves (A), blade length (B), blade width (C) and the blade width/length ratio (D) of $R$. dentatus and $R$. pictus in response to increasing level of $\mathrm{P}$ in a hydroponic culture with $11 \mathrm{mM} \mathrm{N}$ supplied either as $\mathrm{NO}_{3}$ - or $\mathrm{NH}_{4}+$. Each value is the mean of 4 replicates \pm SE.

Plant biochemistry was highly significantly $(\mathrm{P}<0.01)$ affected by the main factors: plant species, nitrogen form and level of phosphorus, except for the non-significant effect of species and level of $\mathrm{P}$ on shoot protein and the non- significant genotype effect on shoot phenolics. Similar to the growth measurements, the effect of the factor interactions on plant biochemistry was less evident than the effect of the main factors (Table 5).

Chlorophyll a concentration was significantly higher in the leaves of $R$. pictus than $R$. dentatus, particularly under high P supply. The differential effect of $\mathrm{N}$ form was evident only in $R$. dentatus, in favor ammonium nutrition but with no effect in $R$. pictus. Increasing P supply increased $\mathrm{Chl}$ a concentration, particularly in $R$. pictus and under nitrate nutrition. The increase in Chl a concentration across the whole range of $P$ supply amounted to 3.5 and 2.2 folds in nitrate- and ammonium-fed $R$. dentatus, respectively and to 4.3 and 3.5 folds in nitrateand ammonium-fed $R$. pictus, respectively (Fig. 3A).

Chlorophyll $\mathrm{b}$ concentration of the leaves was higher in nitrate-fed $R$. dentatus than the other three species $\times \mathrm{N}$ form combinations. In contrast to the response of $\mathrm{Chl} \mathrm{a}$, increasing $\mathrm{P}$ supply decreased Chl b concentration with different patterns according to plant species and $\mathrm{N}$ form; but the magnitude of decrease was generally more evident in $R$. pictus than $R$. dentatus and it was more evident under ammonium nutrition in $R$. dentatus but under nitrate nutrition in $R$. pictus. The decrease in $\mathrm{Chl} \mathrm{b}$ concentration across the whole range of $\mathrm{P}$ levels was less severe (42\%) in nitrate-fed $R$. dentatus than the other species $\times \mathrm{N}$ form combinations with an average reduction of $71 \%$ (Fig. 3B).

Carotenoid concentration was significantly higher in $R$. pictus than $R$. dentatus, and under nitrate than ammonium nutrition. The genotypic difference as well as the $\mathrm{N}$ form effect was most evident at high $\mathrm{P}$ levels, where carotenoid content of nitrate-fed $R$. pictus exhibited the highest level relative to the other species $\times \mathrm{N}$ form combinations. Phosphorus supply differentially affected carotenoid content according to plant species and form of $\mathrm{N}$. Increasing $\mathrm{P}$ level of the medium increased carotenoid concentration by an average of $42 \%$ in nitrate- and ammonium-fed $R$. dentatus and by $91 \%$ in nitrate-fed $R$. pictus versus $20 \%$ reduction in ammonium-fed $R$. pictus (Fig. 3C). Total soluble sugars (TSS) were markedly lower in the ammonium-fed $R$. pictus than the other three species $\times \mathrm{N}$ form combinations. Increasing P supply from 0.01 to $1.5 \mathrm{mM}$ increased TSS of ammonium-fed $R$. dentatus 
and nitrate-fed $R$. pictus by $28 \%$ and $54 \%$, respectively with non-significant effect in nitrate-fed $R$. dentatus and ammonium-fed $R$. pictus (Fig. 4A). Proline concentration was significantly higher in $R$. dentatus than $R$. pictus under ammonium nutrition with weak genotypic difference under nitrate nutrition. It was generally higher in ammonium-fed than nitrate-fed plants. Increasing $\mathrm{P}$ supply from 0.01 to $1.5 \mathrm{mM}$ decreased proline concentration by an average of $40 \%$ for all species $\times \mathrm{N}$ form combinations (Fig. 4B).

Table 4 Effect of nitrogen form and level of phosphorus on plant height and water content of shoot and root of $R$. dentatus and $R$. pictus. Nitrogen was supplied as $\mathrm{NO}_{3}{ }^{-}$or $\mathrm{NH}_{4}{ }^{+}$at a level of $11 \mathrm{mM}$. Each value is the mean of 4 replicates \pm SE. $\neq$

\begin{tabular}{|c|c|c|c|}
\hline $\begin{array}{c}\mathrm{N} \text { form and } \\
\text { level of } \mathrm{P}(\mathrm{mM})\end{array}$ & $\begin{array}{l}\text { Plant height } \\
(\mathrm{cm})\end{array}$ & $\begin{array}{c}\text { Shoot water content } \\
(\% \text { FW })\end{array}$ & $\begin{array}{c}\text { Root water content } \\
(\% \text { FW })\end{array}$ \\
\hline & & Rumex dentatus & \\
\hline \multicolumn{4}{|l|}{ Nitrate } \\
\hline 0.01 & $21.1 \pm 2.68 \mathrm{a}$ & $95.10 \pm 0.60 \mathrm{de}$ & $92.89 \pm 0.83 \mathrm{efg}$ \\
\hline 0.15 & $21.3 \pm 2.02 \mathrm{a}$ & $95.05 \pm 0.36 \mathrm{de}$ & $93.35 \pm 0.80 \mathrm{fg}$ \\
\hline 0.40 & $23.2 \pm 0.68 \mathrm{abcd}$ & $95.12 \pm 0.44 \mathrm{de}$ & $93.03 \pm 0.28 \mathrm{efg}$ \\
\hline 1.00 & $26.8 \pm 0.99 \mathrm{~cd}$ & $94.99 \pm 0.28 \mathrm{de}$ & $94.33 \pm 0.29 \mathrm{fg}$ \\
\hline 1.50 & $27.3 \pm 0.57 \mathrm{~d}$ & $95.26 \pm 0.12 \mathrm{de}$ & $94.93 \pm 0.21 \mathrm{~g}$ \\
\hline \multicolumn{4}{|l|}{ Ammonium } \\
\hline 0.01 & $21.8 \pm 1.78 \mathrm{ab}$ & $91.53 \pm 0.60 \mathrm{ab}$ & $93.37 \pm 1.01 \mathrm{fg}$ \\
\hline 0.15 & $21.2 \pm 0.96 a$ & $91.58 \pm 0.36 \mathrm{ab}$ & $91.88 \pm 0.30 \mathrm{defg}$ \\
\hline 0.40 & $22.8 \pm 1.87 \mathrm{abc}$ & $91.47 \pm 0.44 \mathrm{ab}$ & $91.37 \pm 0.59 \mathrm{def}$ \\
\hline 1.00 & $26.0 \pm 0.49 \mathrm{bcd}$ & $92.33 \pm 0.28 b c$ & $91.27 \pm 0.43 \mathrm{cdef}$ \\
\hline \multirow[t]{2}{*}{1.50} & $25.8 \pm 1.25 \mathrm{bcd}$ & $91.77 \pm 0.12 \mathrm{ab}$ & $91.68 \pm 0.42 \mathrm{defg}$ \\
\hline & & Rumex pictus & \\
\hline \multicolumn{4}{|l|}{ Nitrate } \\
\hline 0.01 & $21.2 \pm 0.67 \mathrm{a}$ & $91.36 \pm 0.77 \mathrm{ab}$ & $81.21 \pm 2.14 \mathrm{a}$ \\
\hline 0.15 & $21.3 \pm 0.71 \mathrm{a}$ & $90.12 \pm 1.65 \mathrm{a}$ & $80.85 \pm 2.53 \mathrm{a}$ \\
\hline 0.40 & $22.3 \pm 1.88 \mathrm{ab}$ & $91.39 \pm 0.62 \mathrm{ab}$ & $81.42 \pm 1.27 \mathrm{a}$ \\
\hline 1.00 & $25.2 \pm 2.29 \mathrm{abcd}$ & $91.98 \pm 0.33 b c$ & $81.01 \pm 0.35 \mathrm{a}$ \\
\hline 1.50 & $26.1 \pm 2.77 \mathrm{bcd}$ & $93.62 \pm 0.34 \mathrm{~cd}$ & $89.85 \pm 0.62 \mathrm{bcde}$ \\
\hline \multicolumn{4}{|l|}{ Ammonium } \\
\hline 0.01 & $21.1 \pm 1.18 \mathrm{a}$ & $92.04 \pm 1.40 b c$ & $83.93 \pm 2.14 a$ \\
\hline 0.15 & $22.3 \pm 1.03 \mathrm{ab}$ & $95.77 \pm 0.38 \mathrm{e}$ & $82.32 \pm 2.53 a$ \\
\hline 0.40 & $23.7 \pm 1.28 \mathrm{abcd}$ & $95.65 \pm 0.82 \mathrm{e}$ & $87.89 \pm 1.27 b c$ \\
\hline 1.00 & $24.3 \pm 1.55 \mathrm{abcd}$ & $95.60 \pm 0.49 \mathrm{e}$ & $87.38 \pm 0.35 b$ \\
\hline 1.50 & $25.7 \pm 1.08 \mathrm{bcd}$ & $96.11 \pm 0.28 \mathrm{de}$ & $88.61 \pm 0.62 \mathrm{bcd}$ \\
\hline
\end{tabular}

Protein concentration of leaves was comparable in the two species and under the two nitrogen forms. It exhibited an average increase of $30 \%$ upon increasing P supply from 0.01 to $0.15 \mathrm{mM}$, followed by $25 \%$ reduction with further increase up to $1.5 \mathrm{mM}$ in $R$. dentatus and $R$. pictus under nitrate nutrition with nonsignificant effect under ammonium nutrition (Fig. 5A). Leaf malondialdehyde (MDA) concentration was significantly higher in $R$. pictus than $R$. dentatus, and under nitrate than ammonium nutrition in $R$. dentatus but with no effect of $\mathrm{N}$ form in $R$. pictus. Increasing $\mathrm{P}$ supply from 0.01 to $1.5 \mathrm{mM}$ halved the MDA content in a progressive manner in $R$. dentatus and across the range $0.01-0.15 \mathrm{mM}$ in $R$. pictus independent of the $\mathrm{N}$ form (Fig. 5B).
Phenolics concentration of leaves was significantly higher in the nitrate-fed $R$. dentatus than the other three species $\times \mathrm{N}$ form combinations. Increasing $\mathrm{P}$ supply from 0.01 to $1.5 \mathrm{mM}$ doubled phenolics concentration in nitrate- and ammonium-fed $R$. dentatus and ammonium-fed $R$. pictus but increased it by 64\% in nitrate-fed $R$. pictus (Fig. 6A). DPPH scavenging activity was significantly higher in the ammonium-fed $R$. pictus than the other three species $\times \mathrm{N}$ form combinations. Increasing $\mathrm{P}$ supply from 0.01 to $1.5 \mathrm{mM}$ increased DPPH scavenging activity by $59 \%$ and $49 \%$ in $R$. dentatus and $R$. pictus, respectively independent of the $\mathrm{N}$ form (Fig. 6B). 
Table 5 Three-way ANOVA showing the effect of the main factors (Rumex species, $\mathrm{N}$ form and level of P) and their interaction on plant biochemistry.

\begin{tabular}{|c|c|c|c|c|c|c|c|}
\hline $\begin{array}{l}\text { Variable and } \\
\text { source of variation }\end{array}$ & $\mathrm{df}$ & $\mathrm{F}$ & $\mathrm{P}$ & $\begin{array}{l}\text { Variable and } \\
\text { source of variation }\end{array}$ & $\mathrm{df}$ & $\mathrm{F}$ & $\mathrm{P}$ \\
\hline Chl a & & & & Protein & & & \\
\hline Species (Sp.) & 1 & 33.09 & 0.000 & Species (Sp.) & 1 & 3.157 & 0.081 \\
\hline $\mathrm{N}$ form $(\mathrm{N})$ & 1 & 7.931 & 0.007 & $\mathrm{~N}$ form $(\mathrm{N})$ & 1 & 10.53 & 0.002 \\
\hline P level (P) & 4 & 593.3 & 0.000 & P level $(\mathrm{P})$ & 4 & 2.255 & 0.074 \\
\hline Sp. $\times N$ & 1 & 18.59 & 0.000 & Sp. $\times N$ & 1 & 3.068 & 0.085 \\
\hline Sp. $\times$ P & 4 & 24.06 & 0.000 & Sp. $\times$ P & 4 & 0.306 & 0.873 \\
\hline $\mathrm{N} \times \mathrm{P}$ & 4 & 1.486 & 0.218 & $\mathrm{~N} \times \mathrm{P}$ & 4 & 1.427 & 0.236 \\
\hline Sp. $\times \mathrm{N} \times \mathrm{P}$ & 4 & 0.455 & 0.769 & Sp. $\times \mathrm{N} \times \mathrm{P}$ & 4 & 2.583 & 0.046 \\
\hline Chl b & & & & Malondialedhyde & & & \\
\hline Species (Sp.) & 1 & 88.93 & 0.000 & Species (Sp.) & 1 & 73.97 & 0.000 \\
\hline $\mathrm{N}$ form $(\mathrm{N})$ & 1 & 23.62 & 0.000 & $\mathrm{~N}$ form $(\mathrm{N})$ & 1 & 10.06 & 0.003 \\
\hline P level (P) & 4 & 36.56 & 0.000 & P level (P) & 4 & 26.58 & 0.000 \\
\hline Sp. $\times N$ & 1 & 78.62 & 0.000 & Sp. $\times \mathrm{N}$ & 1 & 15.66 & 0.000 \\
\hline Sp. $\times P$ & 4 & 3.156 & 0.020 & Sp. $\times P$ & 4 & 3.585 & 0.014 \\
\hline $\mathrm{N} \times \mathrm{P}$ & 4 & 3.752 & 0.009 & $\mathrm{~N} \times \mathrm{P}$ & 4 & 0.177 & 0.949 \\
\hline Sp. $\times N \times P$ & 4 & 7.187 & 0.000 & Sp. $\times N \times P$ & 4 & 0.565 & 0.689 \\
\hline Carotenoids & & & & DPPH scavenging activity & & & \\
\hline Species (Sp.) & 1 & 65.75 & 0.000 & Species (Sp.) & 1 & 77.87 & 0.000 \\
\hline $\mathrm{N}$ form $(\mathrm{N})$ & 1 & 23.17 & 0.000 & $\mathrm{~N}$ form $(\mathrm{N})$ & 1 & 63.85 & 0.000 \\
\hline P level (P) & 4 & 9.222 & 0.000 & P level (P) & 4 & 389.1 & 0.000 \\
\hline Sp. $\times N$ & 1 & 0.269 & 0.606 & Sp. $\times N$ & 1 & 87.57 & 0.000 \\
\hline Sp. $\times$ P & 4 & 2.539 & 0.049 & Sp. $\times \mathrm{P}$ & 4 & 8.428 & 0.000 \\
\hline $\mathrm{N} \times \mathrm{P}$ & 4 & 4.135 & 0.005 & $\mathrm{~N} \times \mathrm{P}$ & 4 & 2.511 & 0.051 \\
\hline Sp. $\times \mathrm{N} \times \mathrm{P}$ & 4 & 2.236 & 0.076 & Sp. $\times \mathrm{N} \times \mathrm{P}$ & 4 & 4.692 & 0.002 \\
\hline TSS & & & & Phenolics & & & \\
\hline Species (Sp.) & 1 & 74.76 & 0.000 & Species (Sp.) & 1 & 3.746 & 0.058 \\
\hline $\mathrm{N}$ form $(\mathrm{N})$ & 1 & 98.23 & 0.000 & $\mathrm{~N}$ form $(\mathrm{N})$ & 1 & 8.436 & 0.005 \\
\hline P level (P) & 4 & 7.482 & 0.000 & P level (P) & 4 & 76.83 & 0.000 \\
\hline Sp. $\times N$ & 1 & 32.94 & 0.000 & Sp. $\times \mathrm{N}$ & 1 & 6.048 & 0.017 \\
\hline Sp. $\times$ P & 4 & 1.040 & 0.394 & Sp. $\times$ P & 4 & 3.372 & 0.015 \\
\hline $\mathrm{N} \times \mathrm{P}$ & 4 & 2.125 & 0.089 & $\mathrm{~N} \times \mathrm{P}$ & 4 & 1.377 & 0.253 \\
\hline Sp. $\times N \times P$ & 4 & 7.830 & 0.000 & Sp. $\times \mathrm{N} \times \mathrm{P}$ & 4 & 2.852 & 0.031 \\
\hline \multicolumn{8}{|l|}{ Proline } \\
\hline Species (Sp.) & 1 & 22.30 & 0.000 & & & & \\
\hline $\mathrm{N}$ form $(\mathrm{N})$ & 1 & 220.1 & 0.000 & & & & \\
\hline P level (P) & 4 & 163.6 & 0.000 & & & & \\
\hline Sp. $\times N$ & 1 & 48.31 & 0.000 & & & & \\
\hline Sp. $\times$ P & 4 & 4.938 & 0.002 & & & & \\
\hline $\mathrm{N} \times \mathrm{P}$ & 4 & 3.769 & 0.008 & & & & \\
\hline Sp. $\times \mathrm{N} \times \mathrm{P}$ & 4 & 1.105 & 0.363 & & & & \\
\hline
\end{tabular}

Three-way ANOVA revealed significant effects of most of the main factors and their interactions on mineral composition of shoot. However, the most affected variable was nitrogen with significant $(\mathrm{P}<0.05)$ to highly significant $(\mathrm{P}<0.01)$ effects of the three main factors and their interactions, followed by the $\mathrm{N} / \mathrm{P}$ ratio. By contrast, the least affected variable was the $\mathrm{K} / \mathrm{Na}$ ratio, with significant effects only of level of $\mathrm{P}$ as well as the species $\times \mathrm{N}$ and $\mathrm{N} \times \mathrm{P}$ interaction (Table 6).

Nitrogen concentration of the shoot was significantly higher in $R$. dentatus than $R$. pictus and under nitrate over ammonium nutrition in $R$. pictus with weak effect of $\mathrm{N}$ form in $R$. dentatus. In nitrate-fed $R$. dentatus, $\mathrm{N}$ concentration of the shoot exhibited $37 \%$ increase with the increase in $\mathrm{P}$ level of the medium from 0.01 to 0.15 followed by $14 \%$ reduction with further increase in $\mathrm{P}$ level up to $1.5 \mathrm{mM}$ but with non-significant changes in the ammonium-fed plants. In $R$. pictus, $\mathrm{N}$ concentration of the shoot increased by $30 \%$ across the whole range of $\mathrm{P}$ in nitrate-fed plants and by $90 \%$ post 0.4 up to $1.5 \mathrm{mM} \mathrm{P}$ in ammonium-fed plants (Fig. 7A).

Phosphorus concentration of the shoot was significantly higher in $R$. pictus than $R$. dentatus under nitrate nutrition but the reverse was true under ammonium nutrition. Regarding the effect of $\mathrm{N}$ form, ammonium nutrition led to higher $\mathrm{P}$ 
concentration of the shoot above nitrate nutrition in $R$. dentatus but such an effect was absent in $R$. pictus. Increasing P supply from 0.01 to $1.5 \mathrm{mM}$ increased shoot $\mathrm{P}$ concentration by $30 \%$ (non-significant) and $150 \%$ in nitrate- and ammonium-fed $R$. dentatus, respectively and by $100 \%$ and $80 \%$ in nitrate- and ammonium-fed $R$. pictus, respectively (Fig. 7B).

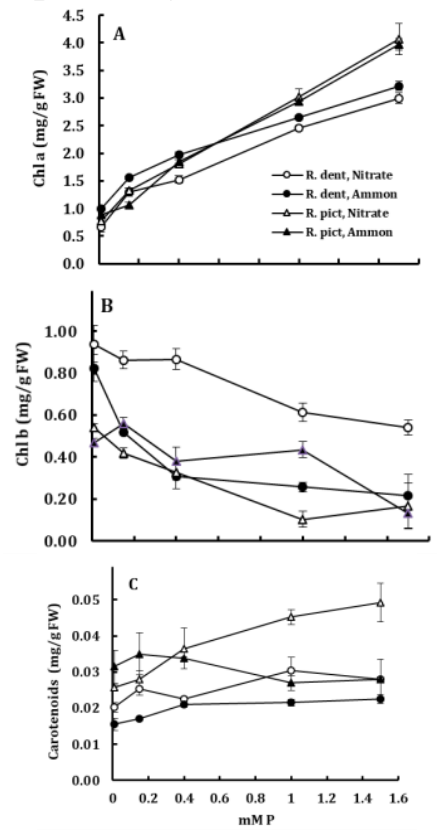

Figure 3 Concentrations of chlorophyll a (A), chlorophyll b (B) and carotenoids (C) in the leaves of R. dentatus and R. pictus in response to increasing level of $\mathrm{P}$ in a hydroponic culture with $11 \mathrm{mM} \mathrm{N}$ supplied either as NO3- or NH4+. Each value is the mean of 4 replicates \pm SE.

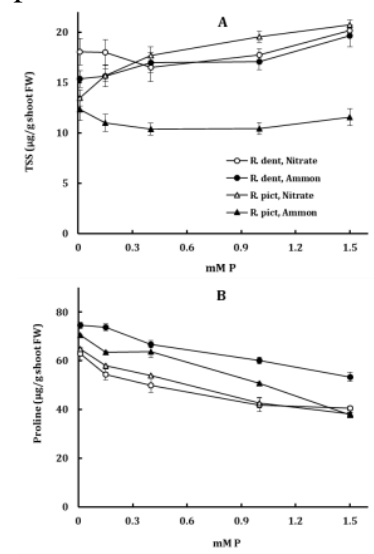

Figure 4 Concentrations of total soluble sugars (A) and proline (B) in the shoots of R. dentatus and $\mathrm{R}$. pectus in response to increasing level of $\mathrm{P}$ in a hydroponic culture with $11 \mathrm{mM}$ N supplied either as NO3- or NH4+. Each value is the mean of 4 replicates $\pm \mathrm{SE}$.

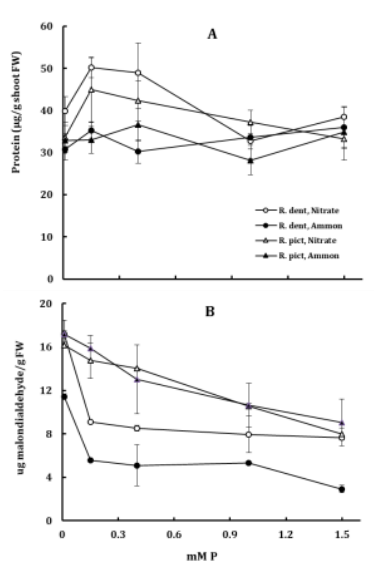

Figure 5 Concentrations of protein (A) and malondialdehyde (B) in the shoots of R. dentatus and $\mathrm{R}$. pictus in response to increasing level of $\mathrm{P}$ in a hydroponic culture with $11 \mathrm{mM} \mathrm{N}$ supplied either as NO3- or NH4+. Each value is the mean of 4 replicates $\pm \mathrm{SE}$.

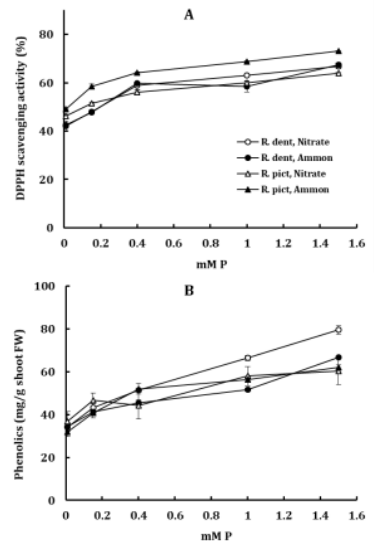

Figure 6 DPPH scavenging activity (A) and concentration of phenolics (B) of the shoots of $R$. dentatus and $R$. pictus in response to increasing level of $\mathrm{P}$ in a hydroponic culture with $11 \mathrm{mM} \mathrm{N}$ supplied either as $\mathrm{NO}_{3}$ - or $\mathrm{NH}_{4}+$. Each value is the mean of 4 replicates $\pm \mathrm{SE}$.

The N/P ratio was significantly higher in $R$. dentatus above $R$. pictus under nitrate nutrition with no genotypic difference under ammonium nutrition. Generally, the N/P ratio was higher under nitrate over ammonium nutrition, particularly in $R$. dentatus. In $R$. dentatus, the N/P ratio was reduced by $20 \%$ with the increase in P level of the medium post 1 up to $1.5 \mathrm{mM}$ under nitrate nutrition; but in ammonium-fed plants, the reduction amounted to $50 \%$ across the moderate $\mathrm{P}$ levels $(0.01-0.4 \mathrm{mM})$ with steady low levels at higher levels. In $R$. pictus, the N/P ratio was increased by $35 \%$ with the increase in $\mathrm{P}$ level of the medium from 0.01 to $0.4 \mathrm{mM}$, followed by $50 \%$ reduction with further increase in $\mathrm{P}$ level up to $1.5 \mathrm{mM}$ under nitrate nutrition. In ammonium-fed $R$. pictus, the reduction amounted to $40 \%$ with the 
increase in $\mathrm{P}$ level of the medium from 0.01 to $0.15 \mathrm{mM}$, followed by $75 \%$ increase with further increase in P level up to $1.5 \mathrm{mM}$ (Fig. 7C).

The concentrations of $\mathrm{K}$ and $\mathrm{Na}$ in the shoot were markedly higher (about twice) in $R$. dentatus than $R$. pictus with non-significant effect of form of $\mathrm{N}$ (Fig. 8A). Increasing $\mathrm{P}$ supply non-significantly affected shoot $\mathrm{K}$ concentration; however, Na concentration was reduced by $22 \%$ and $32 \%$ in nitrate- and ammonium-fed $R$. dentatus, respectively upon increasing $\mathrm{P}$ supply from 0.01 to $1.5 \mathrm{mM}$ with non-significant effect in $R$. pictus (Fig. 8B). The $\mathrm{K} / \mathrm{Na}$ ratio of the shoot was comparable in the two Rumex species and under the two $\mathrm{N}$ forms. Increasing P supply from 0.01 to $1.5 \mathrm{mM}$ had non-significant effect on $\mathrm{K} / \mathrm{Na}$ ratio of nitratefed but increased that of ammonium-fed $R$. dentatus by $66 \%$. In $R$. pictus, increasing $\mathrm{P}$ supply from 0.1 to $1 \mathrm{mM}$ reduced $\mathrm{K} / \mathrm{Na}$ ratio of nitrate-fed plants by $29 \%$, followed by $29 \%$ increase with further increase in P supply up to $1.5 \mathrm{mM}$, but the increase amounted to $45 \%$ across the whole range of $\mathrm{P}$ supply in ammonium-fed plants (Fig. 8C).

Table 6 Three-way ANOVA showing the effect of the main factors (Rumex species, $\mathrm{N}$ form and level of $\mathrm{P}$ ) and their interaction on shoot mineral content.

\begin{tabular}{|c|c|c|c|c|c|c|c|}
\hline $\begin{array}{c}\text { Variable and } \\
\text { source of variation }\end{array}$ & df & $\mathbf{F}$ & $\mathbf{P}$ & $\begin{array}{c}\text { Variable and } \\
\text { source of variation }\end{array}$ & df & $\mathbf{F}$ & $\mathbf{P}$ \\
\hline Shoot N & & & & Shoot K+ & & & \\
\hline Species (Sp.) & 1 & 199.5 & 0.000 & Species (Sp.) & 1 & 1703 & 0.000 \\
\hline $\mathrm{N}$ form $(\mathrm{N})$ & 1 & 9.909 & 0.003 & $\mathrm{~N}$ form $(\mathrm{N})$ & 1 & 10.93 & 0.002 \\
\hline P level (P) & 4 & 15.21 & 0.000 & P level (P) & 4 & 1.035 & 0.397 \\
\hline Sp. $\times N$ & 1 & 4.661 & 0.035 & Sp. $\times N$ & 1 & 1.814 & 0.183 \\
\hline Sp. $\times$ P & 4 & 12.32 & 0.000 & Sp. $\times P$ & 4 & 1.410 & 0.242 \\
\hline $\mathrm{N} \times \mathrm{P}$ & 4 & 11.55 & 0.000 & $\mathrm{~N} \times \mathrm{P}$ & 4 & 8.232 & 0.000 \\
\hline Sp. $\times \mathrm{N} \times \mathrm{P}$ & 4 & 3.774 & 0.008 & Sp. $\times \mathrm{N} \times \mathrm{P}$ & 4 & 7.437 & 0.000 \\
\hline Shoot P & & & & Shoot $\mathrm{Na}+$ & & & \\
\hline Species (Sp.) & 1 & 3.017 & 0.088 & Species (Sp.) & 1 & 403.1 & 0.000 \\
\hline $\mathrm{N}$ form $(\mathrm{N})$ & 1 & 50.10 & 0.000 & $\mathrm{~N}$ form $(\mathrm{N})$ & 1 & 5.509 & 0.022 \\
\hline P level (P) & 4 & 10.21 & 0.000 & P level (P) & 4 & 6.380 & 0.000 \\
\hline Sp. $\times N$ & 1 & 29.54 & 0.000 & Sp. $\times N$ & 1 & 3.629 & 0.062 \\
\hline Sp. $\times$ P & 4 & 0.653 & 0.627 & Sp. $\times$ P & 4 & 2.718 & 0.038 \\
\hline $\mathrm{N} \times \mathrm{P}$ & 4 & 2.268 & 0.072 & $\mathrm{~N} \times \mathrm{P}$ & 4 & 0.295 & 0.880 \\
\hline Sp. $\times \mathrm{N} \times \mathrm{P}$ & 4 & 2.716 & 0.038 & Sp. $\times N \times P$ & 4 & 0.456 & 0.768 \\
\hline Shoot N/P ratio & & & & Shoot K/Na ratio & & & \\
\hline Species (Sp.) & 1 & 51.83 & 0.000 & Species (Sp.) & 1 & 3.621 & 0.062 \\
\hline $\mathrm{N}$ form $(\mathrm{N})$ & 1 & 126.4 & 0.000 & $\mathrm{~N}$ form $(\mathrm{N})$ & 1 & 0.016 & 0.899 \\
\hline P level (P) & 4 & 4.590 & 0.003 & P level (P) & 4 & 3.943 & 0.007 \\
\hline Sp. $\times N$ & 1 & 37.59 & 0.000 & Sp. $\times N$ & 1 & 6.847 & 0.011 \\
\hline Sp. $\times$ P & 4 & 1.824 & 0.136 & Sp. $\times P$ & 4 & 1.817 & 0.137 \\
\hline $\mathrm{N} \times \mathrm{P}$ & 4 & 9.285 & 0.000 & $\mathrm{~N} \times \mathrm{P}$ & 4 & 4.461 & 0.003 \\
\hline Sp. $\times \mathrm{N} \times \mathrm{P}$ & 4 & 3.419 & 0.014 & Sp. $\times \mathrm{N} \times \mathrm{P}$ & 4 & 1.403 & 0.244 \\
\hline
\end{tabular}




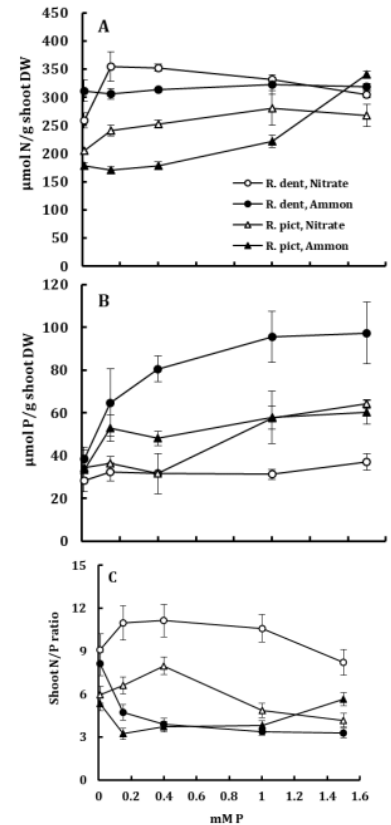

Figure 7 Concentrations of nitrogen (A), phosphorus (B) and the nitrogen/phosphorus ratio (C) in the shoots of $R$. dentatus and $R$. pictus in response to increasing level of $\mathrm{P}$ in a hydroponic culture with $11 \mathrm{mM} \mathrm{N}$ supplied either as $\mathrm{NO}_{3}$ - or $\mathrm{NH}_{4}+$. Each value is the mean of 4 replicates \pm SE.

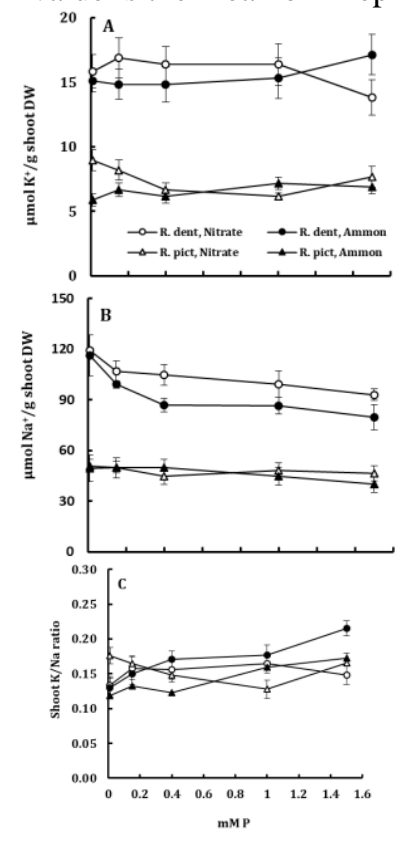

Figure 8 Concentrations of potassium (A), sodium (B) and the potassium/sodium ratio (C) in the shoots of R. dentatus and R. pictus in response to increasing level of $\mathrm{P}$ in a hydroponic culture with $11 \mathrm{mM} \mathrm{N}$ supplied either as NO3- or NH4+. Each value is the mean of 4 replicates \pm SE.

Discussion

Nitrate and ammonium are the major $\mathrm{N}$ sources for higher plants. Compared with ammonium, nitrate is an oxidized anionic form of $\mathrm{N}$; therefore it is more mobile in the soil, more available but less utilizable by plants and safer (Miller and Cramer, 2004). In agricultural soils, nitrate occurs at higher concentrations than ammonium but the reverse is true in unfertilized soils. Soil analysis revealed higher levels of all nutrients, including nitrogen, in the fertilized agricultural soil of $\mathrm{R}$. dentatus than the coastal sand plains of $\mathrm{R}$. pictus.

Plant species differ in their preference to either ammonium or nitrate. Generally, plants adapted to acid soils (calcifuge and wetland species) prefer ammonium whereas those adapted to calcareous high $\mathrm{pH}$ soils (cal $\neg$ cicole species) prefer nitrate (Britto and Kronzucker, 2002). The present work reveals preference of nitrate by the two Rumex species, particularly R. dentatus. In addition, the superiority of $\mathrm{R}$. dentatus growth over R. pictus was particularly evident under nitrate nutrition. This justifies application of nitrate rather than ammonium for R. dentatus, which is widely consumed as a leafy vegetable. This should be done with application of cautious doses to avoid buildup of free non-assimilated nitrate in the plant foliage which can impact human health. In accordance with the present findings. nitrogen form differentially affected plant height in two amaranth varieties, and the genotypic variability was quite evident under nitrate treatment (Munene et al., 2017). However, preference of nitrate by cotton genotypes was not associated with genotype $\times N$ form interaction, and plant performance was not affected by the form of $\mathrm{N}$ (Iqbal et al., 2020). The present work suggests that ammonium nutrition favors plant succulence (more water content of the foliage) in $\mathrm{R}$. pictus while the reverse was true for $\mathrm{R}$. dentatus which exhibited higher water content under nitrate nutrition. The effect on R. pictus can be explained in view of the similarity between NH3 and water in molecular sizes and polarity, allowing NH3 to permeate water channels (Hawkesford et al., 2012).

Phosphorus is the second key plant nutrient after nitrogen. It plays several important roles regarding energy metabolism (in the form of ATP and its analogues) in addition to involvement in phospholipids and nucleic acids (Byrne et al., 2011). Phosphorus concentration of leaves can vary widely without affecting plant performance, because $\mathrm{Pi}$ concentration in the cytosol is adjusted within a narrow range utilizing the vacuolar Pi as a buffer (Mimura et al., 1990). The optimal $\mathrm{P}$ content for plant 
growth is in the range of $0.3-0.5 \% \mathrm{DW}$, but it might be much lower in plants adapted to Pimpoverished soils (Lambers et al., 2011). The P supply optimum for shoot growth of Rumex spp. under nitrate nutrition $(0.4 \mathrm{mM})$ was lower than that required under ammonium nutrition (1.5 $\mathrm{mM} \mathrm{P})$, and the growth promoting effect of increasing $\mathrm{P}$ supply was more evident under ammonium than nitrate nutrition and in $\mathrm{R}$. dentatus than R. pictus.

In P-deficient plants, reductions in the number of leaves and leaf expansion are the most obvious symptoms (Lynch et al., 1991). Leaf expansion may be impaired as a consequence of reduced root hydraulic conductivity (Clarkson et al., 2000). The vigorous species (R. dentatus) was, however, characterized with less number of leaves but longer and wider blades compared with R. pictus; and this pattern was particularly evident under ammonium and low $\mathrm{P}$ nutrition. However, leaf number was negatively correlated to leaf dimensions (Table 7). Leaf width was more sensitive to $\mathrm{P}$ supply in $\mathrm{R}$. pictus than in R. dentatus, but the reverse was true for leaf length.

Compared with shoot growth, root growth was subjected to lesser inhibᄀition under $\mathrm{P}$ deficiency, leading to a typical increase in the plant root/shoot ratio; probably as a consequence of the favored partitioning of carbohydrates and $\mathrm{P}$ towards the roots, along with net translocation of $\mathrm{P}$ from the shoot to the roots (Hawkesford et al., 2012). The more Presponsive R. dentatus was characterized with high RWR relative to R. pictus. It seems that allocation of plant biomass to root (increasing RWR) is favored under ammonium nutrition and $\mathrm{P}$ deficiency, and this pattern was particularly evident in R. pictus.

In con $\neg$ trast to the severe inhibition in leaf expansion under $\mathrm{P}$ defi $\neg$ ciency, the contents of protein and chlorophyll are less affected, leading to higher chlorophyll concentration per unit leaf area (Rao and Terry, 1989). A common symptom of $\mathrm{P}$ deficiency is, thus, the dark green color of foliage, because leaf expan $\neg$ sion is more strongly inhibited than chlorophyll formation (Hawkesford et al., 2012). However, in the two Rumex species increasing P supply increased leaf $\mathrm{Chl} a$ and carotenoid concentrations but reduced $\mathrm{Chl} b$ concentration. Leaves of $\mathrm{R}$ dentatus were characterized with lower Chla and carotenoid contents but higher $\mathrm{Chl} \mathrm{b}$ content relative to $\mathrm{R}$. pictus. It can be concluded that ammonium nutrition favors $\mathrm{Chl}$ a formation whereas nitrate favors $\mathrm{Chl} \mathrm{b}$ and carotenoid formation. In cotton, ammonium nutrition reduced leaf chlorophyll compared with nitrate nutrition (Iqbal et al., 2020).

One of the symptoms of ammonium toxicity is depletion of the plant carbohydrate reserves to the point of starvation as a consequence of excessive con $\neg$ sumption of sugars for ammonium assimilation (Iqbal et al., 2020). Nevertheless, ammonium nutrition led to the highest sugar concentrations in carrot relative to the other N sources (Smolen and Sady, 2009). By contrast, accumulation of soluble sugars and starch in the leaves is a typical symptom of $\mathrm{P}$ deficiency, as a result of either lower phloem loading, lower demand at the sink (Rao et al., 1990) or more suppression of shoot growth compared with photosynthesis (De Groot et al., 2003). In the present work, the effect of $\mathrm{N}$ form on sugar concentration of shoot was evident only in R. pictus, where nitrate nutrition led to higher levels of soluble sugars compared with ammonium.

In addition, the effect of $\mathrm{P}$ supply was limited with mild increase in total sugar content under high $\mathrm{P}$ supply only in nitrate-fed $R$. pictus and ammonium-fed $R$. dentatus.

Under stress conditions, protein synthesis may be inhibited in favor of the accumulation of a number of amino acids (e.g., glycine betaine and proline). These soluble nitrogen compounds are involved in osmotic adjustment, protection of enzymes or detoxification of reactive oxygen species (Radyukina $\boldsymbol{e t}$ al., 2008). Proline accumulation is a well-known response to water and salt stresses in plants (Hawkesford et al., 2012). The present findings of higher proline concentration under ammonium nutrition compared with nitrate nutrition, in $R$. dentatus compared with $R$. pictus and under low $\mathrm{P}$ supply relative to high $\mathrm{P}$ supply suggests that ammonium, as a sole $\mathrm{N}$ source might represent stressful conditions, compared with nitrate particularly to $R$. dentatus and under $\mathrm{P}$ shortage. Meanwhile, protein concentration was non-significantly different in the two species and under the two nitrogen forms. Only $\mathrm{P}$ supply exerted a mild effect, where both $\mathrm{P}$ starvation and excess led to marginal reduction in protein content of Rumex leaves. This might suggest that the increased proline content of Rumex leaves under $\mathrm{P}$ deficiency and ammonium nutrition is not a 
consequence of impaired protein synthesis. Phenolics are secondary plant metabolites that might play pivotal role in plant protection against a variety of biotic and abiotic stresses (Munene et al., 2017). Accumulation of phenolics has been reported under deficiency of $\mathrm{N}, \mathrm{K}, \mathrm{Ca}, \mathrm{B}$ and $\mathrm{Cu}$ (Broadley et al., 2012). The present work revealed marked effect of $\mathrm{N}$ form on shoot phenolics only in $R$. dentatus, where the stressing nitrate nutrition led to higher phenolics concentration relative to ammonium. Increasing $\mathrm{P}$ supply increased phenolics concentration. The effect of $\mathrm{N}$ form on phenolics accumulation can vary according to plant species and susceptibility to ammonium toxicity. Ammonium nutrition stimulated accumulation of phenolics in the ammonium- sensitive Matricaria chamomilla (Kováčik and Klejdus, 2014) and amaranth (Munen et al., 2017), whereas urea fertilization reduced phenolic concentration in cabbage leaves (Leja et al., 2005). In the present work, shoot biomass was positively correlated with leaf phenolics in contrast to the negative correlation between phenolics concentration and plant height of amaranth (Munen et al., 20217). DPPH scavenging activity was intimately correlated to leaf phenolics content of Rumex is in agreement with the findings of Munen et al. (2017) with amaranth but in contrast to Leja et al. (2005) with cabbage where the changes in phenolics did not correspond to radical scavenging activity.

Table 7 Correlation analysis of the performance of the two Rumex species in response to $\mathrm{N}$ form and level of $\mathrm{P}$ of the medium in a hydroponic culture.

\begin{tabular}{|c|c|c|c|c|c|c|c|c|c|c|c|c|c|}
\hline & NOL & $\mathbf{L L}$ & LW & $\begin{array}{l}\text { W/L } \\
\text { ratio }\end{array}$ & Sh DW & Chl a & Chl b & Carot & DPPH & Phenol & Proline & SS & Protein \\
\hline LL & $-\cdots$ & & & & & & & & & & & & \\
\hline LW & - - & +++ & & & & & & & & & & & \\
\hline ratio & & & & & & & & & & & & & \\
\hline W/L & - & ns & +++ & & & & & & & & & & \\
\hline Sh DW & ns & +++ & ++ & ns & & & & & & & & & \\
\hline Chl a & +++ & +++ & ++ & ns & +++ & & & & & & & & \\
\hline Chl b & - - - & ns & ns & + & - - - & - - - & & & & & & & \\
\hline Carot & - - & ns & - - & - & ns & +++ & - & & & & & & \\
\hline DPPH & +++ & +++ & ns & ns & +++ & +++ & - & ++ & & & & & \\
\hline Phenol. & ns & +++ & +++ & ns & +++ & +++ & - - - & + & +++ & & & & \\
\hline Proline & - & - & ns & ns & - - - & - - - & +++ & - & - - - & - - & & & \\
\hline SS & - & +++ & +++ & + & +++ & + & ns & $-\ldots$ & +++ & ++ & - - & & \\
\hline Protein & ns & ns & ns & ns & - & ns & + & ns & ns & ns & ++ & - & \\
\hline MDA & ns & $\ldots$ & - & -- & -- & $\ldots$ & + & ns & $\ldots$ & $-\ldots$ & +++ & $-\ldots$ & ns \\
\hline
\end{tabular}

+++ and --- denote very highly significant $(\mathrm{P}<0.001)$ positive and negative correlation, respectively, ++ and -highly significant $(\mathrm{P}<0.01)$ correlation, + and - significant $(\mathrm{P}<0.05)$ correlation and ns non-significant $(\mathrm{P}>0.05)$ correlation.

$\mathrm{NOL}=$ number of leaves, $\mathrm{LL}=$ leaf length, $\mathrm{LW}=$ leaf width, $\mathrm{W} / \mathrm{L}=$ leaf width/length ratio, $\mathrm{DPPH}=\mathrm{DPPH}$ scavenging activity, $\mathrm{SS}=$ soluble sugars

The present findings suggest that malondialdehyde (MDA) concentration of Rumex shoot was high under the stress conditions of $\mathrm{P}$ shortage with variable effect of $\mathrm{N}$ form in the two species, with strong negative correlation with plant growth and pigment content (Table 7). Accumulation of malondialdehyde (MDA) in wheat leaves, as a sign of oxidative stress, was more expressed in nitrate-fed plants than in ammonium-fed plants (Polesskaya et al., 2006). The advantage of $\mathrm{NH}_{4}{ }^{+}$nutrition to Spartina alterniflora was associated with high antioxidant enzyme activities, together with low MDA content (Hessini et al., 2013).

Ammonium and nitrate constitute about $80 \%$ of the total cations and anions, respectively taken up by plants; therefore, the form of $\mathrm{N}$ can determine the uptake of other cations and anions. Generally, compared with nitrate, ammonium nutrition favors accumulation of inorganic anions such as $\mathrm{Cl}^{-}, \mathrm{SO}_{4}{ }^{2-}$ and $\mathrm{H}_{2} \mathrm{PO}_{4}^{-}$ but reduces the uptake of cations such as $\mathrm{K}^{+}$, $\mathrm{Ca}^{2+}$ and $\mathrm{Mg}^{2+}$ (Britto and Kronzucker, 2002). Ammonium ion $\left(\mathrm{NH}_{4}{ }^{+}\right)$resembles $\mathrm{K}^{+}$in ionic radius and size of hydration shells (Howitt and Udvardi, 2000); therefore, it can compete with $\mathrm{K}^{+}$for plant uptake (ten Hoopen et al., 2010). Nevertheless, the low $\mathrm{K}^{+}$concentrations of $\mathrm{NH}_{4}{ }^{+}$-fed plants may lead to up-regulation of $\mathrm{K}^{+}$ channels in order to improve the plant $\mathrm{K}^{+}$uptake (ten Hoopen et al., 2010). However, the concentrations of $\mathrm{K}^{+}$and $\mathrm{Na}^{+}$in the shoot of Rumex spp. were marginally affected by the treatments; only the genotypic variability was 
marked in favor of $R$. dentatus. Increasing $\mathrm{P}$ supply non-significantly affected shoot $\mathrm{K}^{+}$ concentration but reduced $\mathrm{Na}^{+}$concentration, with a consequent increase in the $\mathrm{K} / \mathrm{Na}$ ratio. The reports about the effect of $\mathrm{P}$ supply on mineral composition of plants are few. Increasing P supply had been found to increase concentrations of $\mathrm{Na}^{+}$in several legume species; with variable effect on $\mathrm{K}^{+}$ concentration according to the species (Andrew and Robins, 1969). A negative correlation has been reported between concentrations of $\mathrm{P}$ and $\mathrm{K}^{+}$in rice straw versus a positive correlation in the grain (Saleque $\boldsymbol{e t}$ al., 2001).

The present work suggests higher uptake of nitrogen by Rumex spp. as nitrate than as ammonium. Also, there was a marked genotypic variability in $\mathrm{N}$ uptake in favor of $R$. dentatus above $R$. pictus. Thus, for Rumex spp., the preference of either $\mathrm{N}$ form (nitrate or ammonium) for plant growth and for uptake by the plant are correlated. In agreement with the present findings, nitrate was more available $\mathrm{N}$ source to cotton than ammonium (Iqbal et al., 2020). By contrast, Serna et al. (1992) reported faster absorption of ammonium than nitrate by citrus seedlings; whereas Abbes et al. (1995) reported no influence of $\mathrm{N}$ form on uptake of $\mathrm{N}$ by onion seedlings. The increased $\mathrm{P}$ concentration of Rumex shoot in response to increasing $\mathrm{P}$ supply was more evident in ammonium-fed than nitrate-fed plants. Ammonium nutrition led to higher $\mathrm{P}$ concentration of the shoot compared with nitrate nutrition only in $R$. dentatus. Higher concentrations of $\mathrm{N}$ and $\mathrm{P}$ in watermelon seedlings were found under mixed nitrate and ammonium sources compared with either nitrate or ammonium alone (Na et al., 2014). Leaf concentration of $\mathrm{N}$ and $\mathrm{P}$ of citrus seedlings were higher under ammonium than nitrate nutrition (Serna et al., 1992). The differential effect of treatments on the uptake of $\mathrm{N}$ and $\mathrm{P}$ led to marked effects on the N/P ratio of shoot. Generally, the N/P ratio was higher under nitrate over ammonium nutrition, particularly in $R$. dentatus.

\section{References}

Abbes C, Parent LE, Karam A, Isfan D (1995) Effect of $\mathrm{NH} 4+$ : NO 3-ratios on growth and nitrogen uptake by onions. Plant and Soil, 171(2), 289-
296.

Ainsworth EA, Gillespie KM (2007) Estimation of total phenolic content and other oxidation substrates in plant tissues using Folin-Ciocalteu reagent. Nature Protocols 2(4): 875.

Allen SE, Grimshaw HM, Rowland AP (1986) Chemical analysis. In: Methods in Plant Ecology (eds P D Moore and SB Chapman), 285- 344. Blackwell, Oxford.

Andrew CS, Robins MF (1969) The effect of phosphorus on the growth and chemical composition of some tropical pasture legumes. II. Nitrogen, calcium, magnesium, potassium, and sodium contents. Crop and Pasture Science 20(4): 675-685.

Bates LS, Waldren RP, Teare ID (1973) Rapid determination of free proline for water-stress studies. Plant Soil 39(1): 205-207.

Bradford MM (1976) A rapid and sensitive method for the quantitation of microgram quantities of protein utilizing the principle of protein- dye binding. Anal. Biochem. 72(1-2): 248-254.

Britto DT, Kronzucker HJ (2002) NH4+ toxicity in higher plants: a critical review. J Plant Physiol. 159: 567-584.

Broadley M, Brown P, Cakmak I, Rengel Z, Zhao F (2012) Function of nutrients: micronutrients. In: Marschner P (ed) Marschner's mineral nutrition of higher plants, 3rd Edn. Academic Press, London, pp 191-248.

Byrne SL, Foito A, Hedley PE, Morris JA, Stewart D, Barth S (2011) Early response mechanisms of perennial ryegrass (Lolium perenne) to phosphorus deficiency. Ann. Bot. 107: 243-254.

Clarkson DT, Carvajal M, Henzler T, Waterhouse RN, Smyth AJ, Cooke DT, Steudle E (2000) Root hydraulic conductance: diurnal aquaporin expression and the effects of nutrient stress. J. Exp. Bot. 51: 61-70.

de Groot CC, van den Boogaard R, Marcelis LFM, Harbinson J, Lambers H (2003) Contrasting effects of $\mathrm{N}$ and $\mathrm{P}$ deprivation on the regulation of photosynthesis in tomato plants in relation to feedback limitation. J. Exp. Bot. 54: 1957-1967.

Hatano T, Kagawa H, Yasuhara T, Okuda T (1988) Two new flavonoids and other constituents in licorice root: their relative astringency and radical scavenging affects. Chem. Pharm. Bull. 36:2090-2097

Hawkesford M, Horst W, Kichey T, Lambers H, Schjoerring J, Møller IS, White P (2012) Functions of macronutrients. In: Marschner $\mathrm{P}$ (ed) Marschner's mineral nutrition of higher plants, Academic Press, London, pp. 135-189.

He H, Wu M, Guo L, Fan C, Zhang Z, Su R, Peng Q, Pang J, Lambers H (2020) Release of tartrate as a major carboxylate by alfalfa (Medicago 
sativa L.) under phosphorus deficiency and the effect of soil nitrogen supply. Plant Soil 449: 169-178.

Heath RL, Packer L (1968) Photoperoxidation in isolated chloroplasts. 1. Kinetics and stiochiometry of fatty acid peroxidation. Arch. Biochem. Biophys. 125:189-198.

Hessini K, Hamed KB, Gandour M, Mejri M, Abdelly C, Cruz C (2013) Ammonium nutrition in the halophyte Spartina alterniflora under salt stress: evidence for a priming effect of ammonium?. Plant Soil 370(1-2): 163-173.

Howitt SM, Udvardi MK (2000) Structure, function and regulation of ammonium transporters in plants. Biochim. Biophys. Acta 1465: 152-170.

Iqbal A, Dong Q, Wang X, Gui HP, Zhang H, Pang N, Zhang X, Song M (2020) Nitrogen preference and genetic variation of cotton genotypes for nitrogen use efficiency. J. Sci. Food Agric. 100(6): 2761-2773.

Jackson M.L. (1962). Soil Chemical Analysis. Constable and Co Ltd, London.

Kováčik J, Klejdus B (2014) Induction of phenolic metabolites and physiological changes in chamomile plants in relation to nitrogen nutrition. Food Chem. 142: 334-341.

Laliberté E, Lambers H, Burgess TI, Wright SJ (2015) Phosphorus limitation, soil-borne pathogens and the coexistence of plant species in hyperdiverse forests and shrublands. New Phytol. 206(2): 507-521.

Lambers H, Plaxton WC (2018) Phosphorus: back to the roots. Annual Plant Reviews online, 3-22.

Lambers H, Shane MW, Cramer MD, Pearse SJ, Veneklaas EJ (2006) Root structure and functioning for efficient acquisition of phosphorus: matching morphological and physiological traits. Ann. Bot. 98: 693-713.

Lambers H, Brundrett MC, Raven JA, Hopper SD (2010) Plant mineral nutrition in ancient landscapes: high plant species diversity on infertile soils is linked to functional diversity for nutritional strategies. Plant Soil 334: 11-31.

Lambers H, Martinoia E, Renton M (2015) Plant adaptations to severely phosphorusimpoverished soils. Curr. Opin. Plant Biol. 25: 23-31.

Leja M, Wyżgolik G, Mareczek A (2005) Phenolic compounds of red cabbage as related to different forms of nutritive nitrogen. Sodininkystė ir Daržininkystè, 24(3): 421-428.

Lynch J, Läuchli A, Epstein E (1991) Vegetative growth of the common bean in response to phosphorus nutrition. Crop Sci. 31: 380-387.

McKay Fletcher DM, Ruiz S, Dias T, Petroselli C, Roose T (2020) Linking root structure to functionality: the impact of root system architecture on citrate-enhanced phosphate uptake. New Phytol. 227: 376-391.

Mashaly IA, El-Habashy IE, El-Halawany EF, Omar G (2008) Habitats and plant communities in the Nile Delta of Egypt I. Deltaic Mediterranean coastal habitat. Pakistan Journal of Biological Sciences 11(22): 2532-2544.

Mashaly IA, Abu-Ziada ME, El-Amier YA, Khorshied RM (2015) Ecological study on two species of genus Rumex in the Nile Delta, Egypt. J. Environ. Sci. 44(2): 403-425.

Miller AJ, Cramer MD (2004) Root nitrogen acquisition and assimilation. Plant Soil 274: 136.

Mimura T, Dietz K-J, Kaiser W, Schramm MJ, Kaiser G, Heber U (1990) Phosphate transport across biomembranes and cytosolic phosphate homeostasis in barley leaves. Planta 180: 139146.

Munene R, Changamu E, Korir N, Joseph GO (2017) Effects of different nitrogen forms on growth, phenolics, flavonoids and antioxidant activity in amaranth species. Trop. Plant Res. 4(1): 81-89.

Na L, Li Z, Xiangxiang M, Ara N, Jinghua Y, Mingfang Z (2014) Effect of nitrate/ammonium ratios on growth, root morphology and nutrient elements uptake of watermelon (Citrullus lanatus) seedlings. J. Plant Nutr. 37(11): 18591872.

Niu YF, Chai RS, Jin GL, Wang H, Tang CX, Zhang YS (2013) Responses of root architecture development to low phosphorus availability: a review. Ann. Bot. 112(2): 391-408.

Piper CS (1947). Soil and Plant Analysis, Inter science Publisher Inc. New York.

Polesskaya OG, Kashirina EI, Alekhina ND (2006) Effect of salt stress on antioxidant system of plants as related to nitrogen nutrition. Russ. J. Plant Physiol. 53(2): 186-192.

Radyukina N, Shashukova A, Shevyakova N, Kuznetsov VI (2008) Proline involvement in the common sage antioxidant system in the presence of $\mathrm{NaCl}$ and paraquat. Russ. J. Plant Physiol. 55: 649-656.

Rao IM, Terry N (1989) Leaf phosphate status, photosynthesis, and carbon partitioning in sugar beet. I. Changes in growth, gas exchange, and Calvin cycle enzymes. Plant Physiol. 90: 814819.

Rao IM, Fredeen AL, Terry N (1990) Leaf phosphate status, photosynthesis, and carbon partitioning in sugar beet. III. Diurnal changes in carbon partitioning and carbon export. Plant Physiol. 92: 29-36.

Saleque MA, Abedin MJ, Ahmed ZU, Hasan M, Panaullah GM (2001) Influences of phosphorus deficiency on the uptake of nitrogen, potassium, 
calcium, magnesium, sulfur, and zinc in lowland rice varieties. J. Plant Nutr. 24(10): 1621-1632.

Schlüter U, Crawford RM (2003) Metabolic adaptation to prolonged anoxia in leaves of American cranberry (Vaccinium macrocarpon). Physiol. Plant. 117(4): 492-499.

Serna MD, Borras R, Legaz F, Primo-Millo E (1992) The influence of nitrogen concentration and ammonium/nitrate ratio on $\mathrm{N}$-uptake, mineral composition and yield of citrus. Plant Soil 147(1): 13-23.

Simpson RJ, Oberson A, Culvenor RA, Ryan MH, Veneklaas EJ, Lambers H, Lynch JP, Ryan PR, Delhaize E, Smith FA, Smith SE, Harvey PR, Richardson AE (2011) Strategies and agronomic interventions to improve the phosphorus-use efficiency of farming systems. Plant Soil 349(12): 89-120.

Smolen S, Sady W (2009) The effect of various nitrogen fertilization and foliar nutrition regimes on the concentrations of sugars, carotenoids and phenolic compounds in carrot (Daucus carota L.). Sci. Hortic. 120(3): 315-324.

ten Hoopen F, Cuin TA, Pedas P, Hegelund JN, Shabala S, Schjoerring JK, Jahn TP (2010) Competition between uptake of ammonium and potassium in barley and Arabidopsis roots. Molecular mechanisms and physiological consequences. J. Exp. Bot. 61: 2303-2315.

Vasas A, Orbán-Gyapai O, Hohmann J (2015) The Genus Rumex: Review of traditional uses, phytochemistry and pharmacology. Journal of Ethnopharmacology 175: 198-228.

Wellburn AR, Lichtenhaler H (1984) Formulae and program to determine total carotenoids and chlorophylls a and b leaf extracts in different solvents. In: Advances in Photosynthesis Research (ed. C. Sypesma), Vol. II: 9-12. Mertinus Njihoff/ Dr. Junk Publishers.

\section{عنوان البحث: تأثير شكل المصدر النيتروجيني في الاستجابة للفوسفور في نوعين من جنس الحميض في المنطقة الساحلية لالتا النيلّ فئي}

يشكل النيتروجين و الفوسفور مغذيات محددة للنبات في الأر اضي الحديثة والناضجة على التو الي. تم در اسة

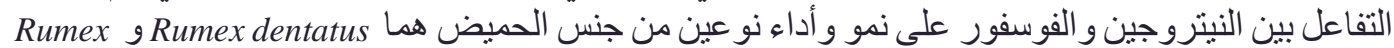

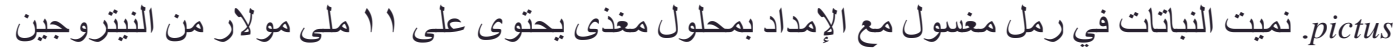

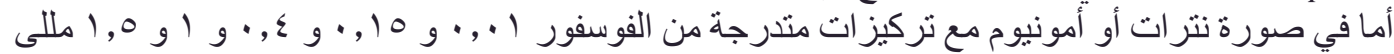

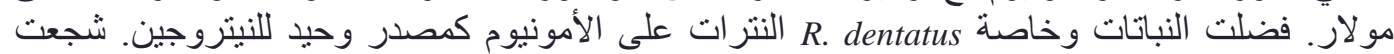

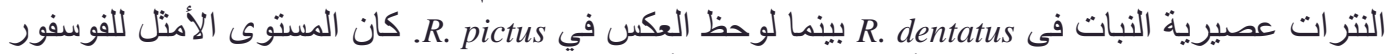

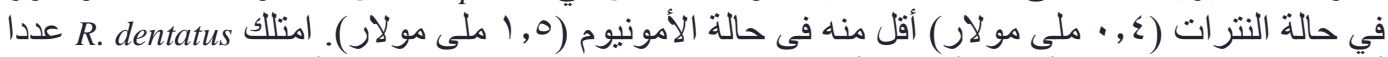

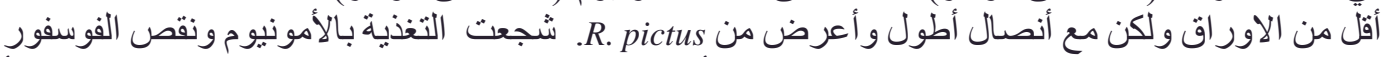

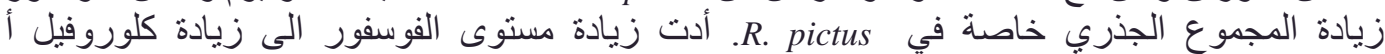

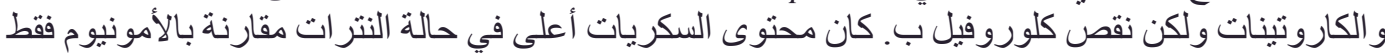

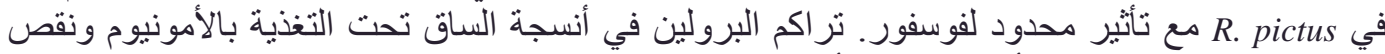

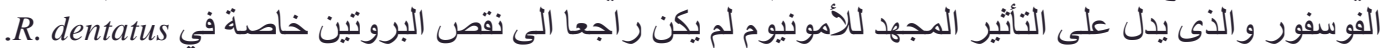

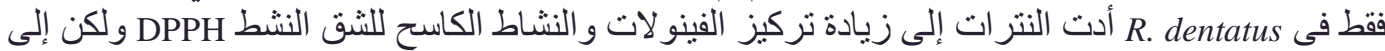

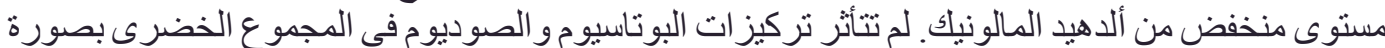

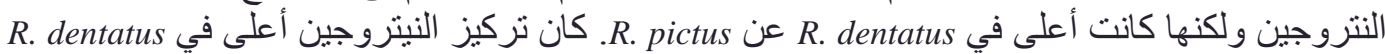

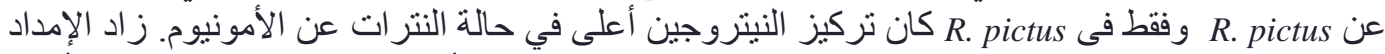

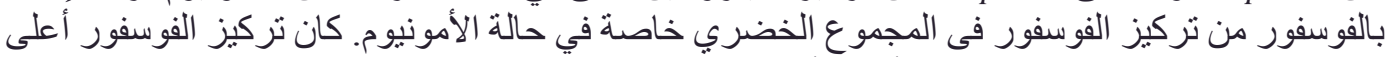

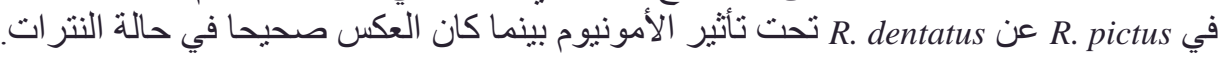

